\title{
Las ciudades representadas en el mosaico bizantino de "La Carta» de Madaba. Origen y paralelos
}

\author{
Guadalupe López Monteagudo *
}

\section{RESUMEN ABSTRACT}

En el mosaico de la Carta de Madaba

se encuentran distintos tipos de edificaciones, algunos de carácter realista y otros de contenido simbólico, al igual que ocurre en otros documentos de los siglos $V$ al VIII. Interesa resaltar las formas arquitectónicas como reminiscencias de modelos antiguos de época romana.
In the mosaic of the Chart of Madaba we can find different kinds of constructions, some of them of a realistic nature, others of a more symbolic type, as in others documents of the Vth to the VIIIth centuries. We would like to underline the architectonic shapes as reminiscences of earlier models dating from the Roman age.

El mosaico de "La Carta" de Madaba (Jordania), fechado a mediados del siglo vi d.C., constituye una fuente histórica excepcional por su valor documental, ya que, a través de las inscripciones que acompañan a los edificios representados, se nos han transmitido los lugares de época bíblica, cuyo punto culminante lo constituye la viñeta de Jerusalén (Hagiapolis), distribuidos por una amplia área geográfica que se extiende desde Egipto, al Sur, hasta la costa fenicia, al Norte, y desde el desierto, al Este, hasta el Mar Mediterráneo, al Oeste, todo ello organizado en torno a un eje central que discurre de Norte a Sur, formado por el curso del río Jordán y la depresión del Mar Muerto (figura 1) '. A pesar de las lagunas que presenta,

CSIC

M. Piccirill o. Madaba. Le chiese e i mosaici. Milano 1989, págs. 81-95: iD.. The Mosaics of Jordan. Amman 1993, págs. 26-34, 81-95. pl. 57-75. 


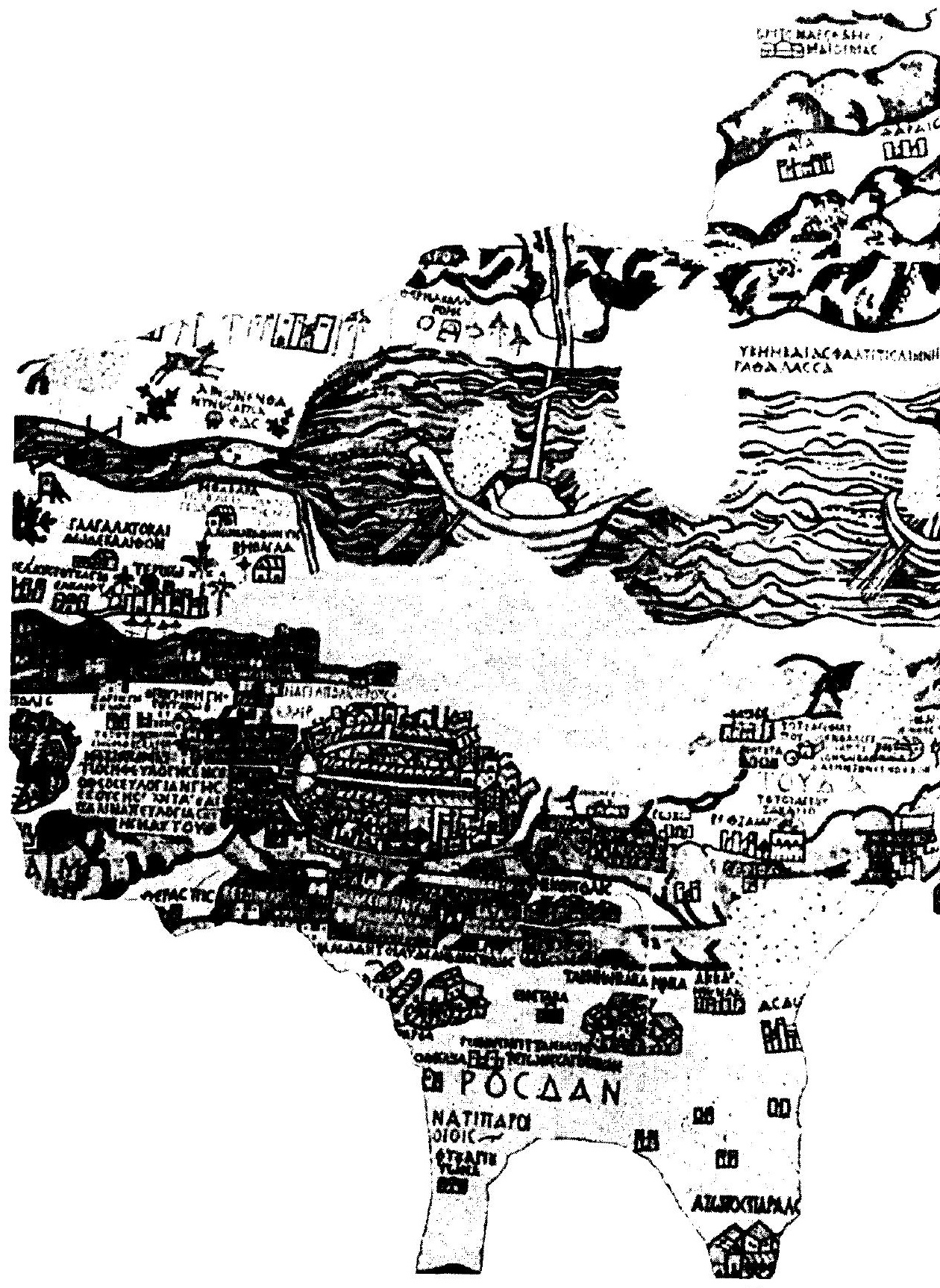

Figura 1. Madaba 
en el mosaico de Madaba se distinguen varios tipos de edificaciones utilizados para representar las ciudades, uno de carácter realista y otro de contenido simbólico, al igual que ocurre en otros documentos de los siglos $V I$ al VIII ${ }^{2}$. Hay representaciones de intención realista que, pese al esquematismo convencional, a veces han ayudado al estudio topográfico de las ciudades antiguas y a la reconstrucción de ciertos monumentos, como ocurre en las orlas de los pavimentos de la Megalopsiquia de Antioquía ${ }^{3}$, de época constantiniana, o en las de Ma'in y de la iglesia de San Esteban en Umm al-Rasas, ya de época bizantina ${ }^{4}$. Pero también hay imágenes simbólicas de edificios con las que se pretende no reproducir una construcción real, sino destacarlos en función de su significado. En todo caso, lo que interesa resaltar en las edificaciones de Madaba no es tanto lo ideológico como lo formal, es decir, las formas arquitectónicas desvinculadas de su contenido simbólico, como reminiscencias de modelos anteriores que remontan a la tradición clásica y que se encuentran perfectamente documentados sobre todo en mosaicos romanos a partir del siglo III d.C. 5 .

Las arquitecturas representadas en el mosaico jordano obedecen "grosso modo" a cinco tipos diferentes, cuatro se han utilizado para figurar ciudades y uno para templos y edificios urbanos. Entre los primeros se distinguen fundamentalmente dos modelos: uno esquemático, constituido por representaciones simplificadas de ciudades, reducidas a puertas flanqueadas por dos torres, a veces con indicación de una construcción central, y ciudades amuralladas vistas frontalmente, con muralla contínua y torres de tejado plano, cuyo número varía según la importancia de la ciudad; y otro de origen helenístico, en el que se encuadran las ciudades vistas en su conjunto con indicación de algunos edificios, peristilos y calles columnadas, así como ciudades amuralladas y planimétricas, de distinto tamaño e importancia, figuradas a "vista de pájaro".

I. EMRENSPERGER-KATZ, Les répresentations de villes fortifiées dans l'art paléochrétien et leurs dérivées byzantines, Cahiers Archéologiques XIX, 1969, págs. 1-27 G. MANSUEILI, La rappresentazione della città nell'arte tardo-romana e bizantina, XIX Corsi di Cultura sull'arte ravennate e bizantina, 1972, págs. 239-244; J. DECKERS, Tradition und Adaption. Bemerkungen zur Darstellung der christlichen Stadt, RM. 95, 1988, págs. 303-382

D. LEvi, Antioch Mosaic Pavements, Princeton 1947, págs. 326-337, pl. LXX|X-LXXX

4 M. PICCIRILLO. The Mosaics at Um er-Rasas in Jordan, BA 51/4, 1988, págs. 208 ss.; ID. Madaba. Le chiese e i mosaici, Milano 1989, págs. 226-234, 269-303; M. Piccirillo-E. Alliata, Umm Al-Rasas. Mayfa'ah. I. Gli scavi del complesso di Santo Stefano, Jerusalem 1994.

G. Lopez Monteagudo, En el centenario del descubrimiento del mapa de Madaba (Jordania), Revista de Arqueologia. $n^{\circ}$ 200, 1997, págs. 46-53: ID.. The Maps in the Byzantine Period. Origin and Transfer of the architectonic Models on the Mosaic and Picture from Spain, International Co Iloquium "The Madaba Map Centenary 1897-1997: Travelling through the Byzantine-Umayyad Pe riod" (Amman-Jordania, 1997), en prensa. 


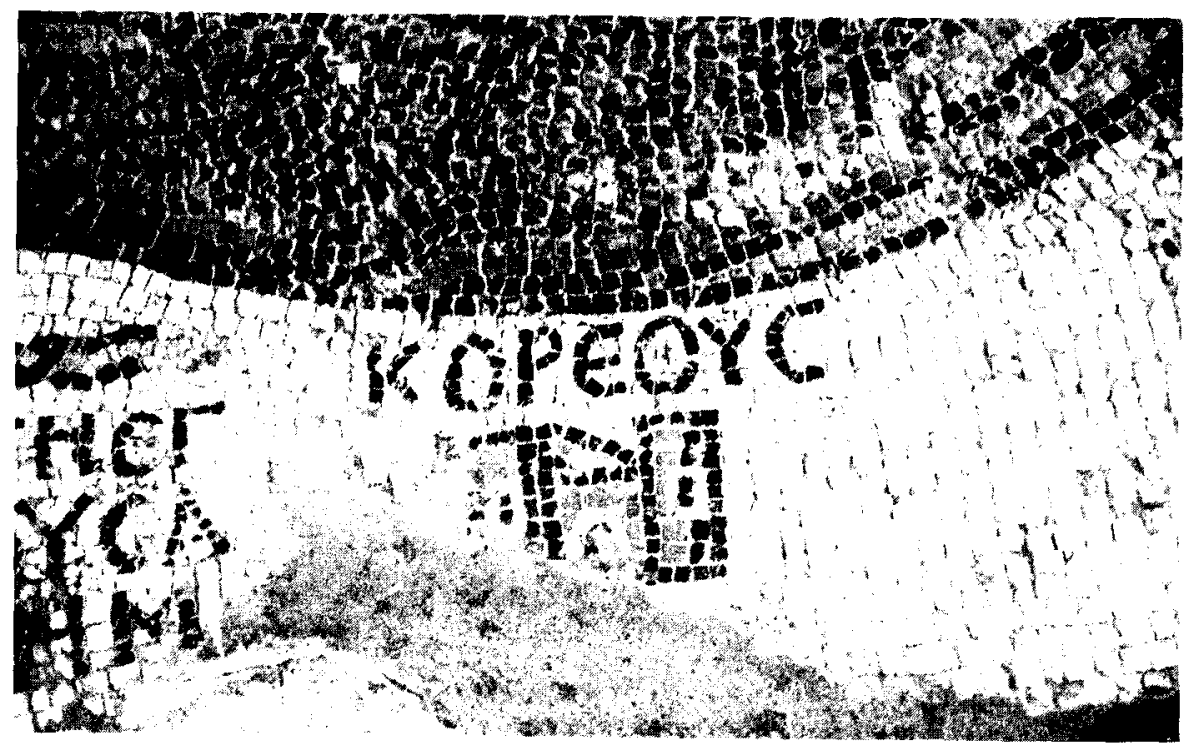

Figura 2. Mosaico de Madaba. Coreus. Foto G. López Monteagudo.

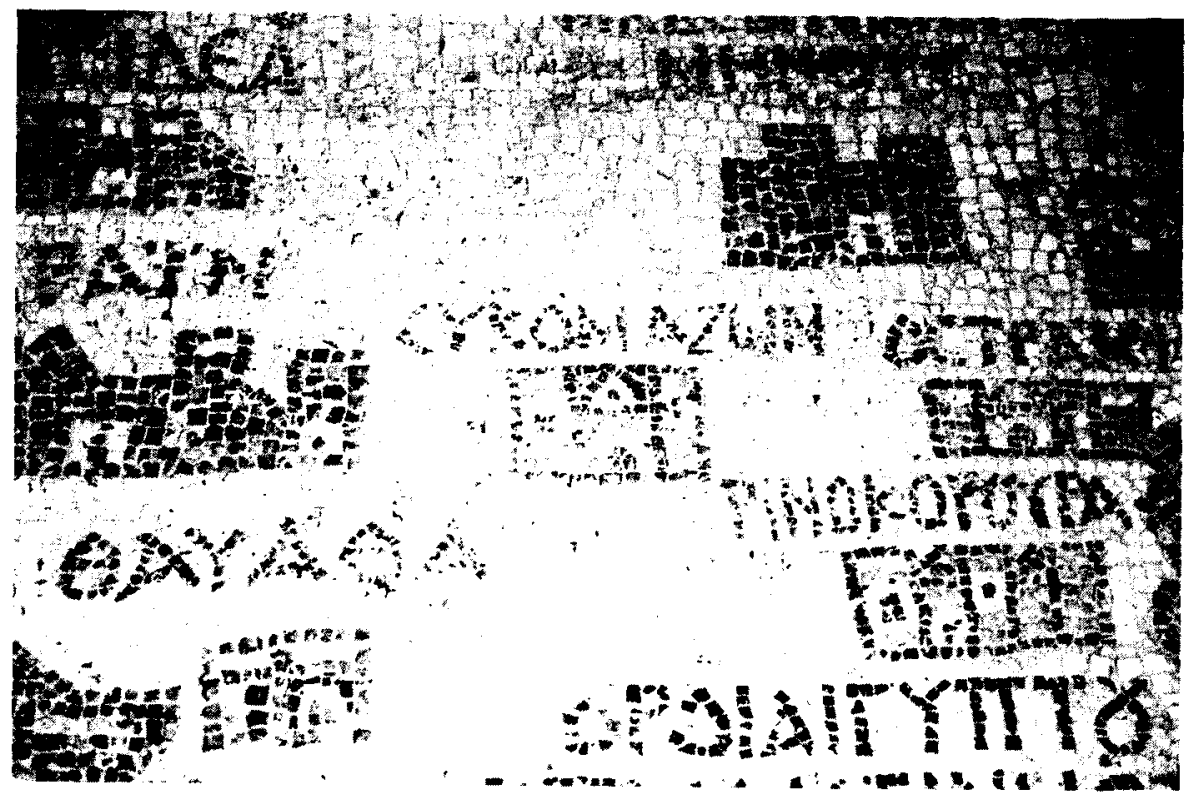

Figura 3. Mosaico de Madaba. Minois, Ostracine, Rinocorura. Sicomazón y Thauatha. Foto G. Lopez Monteagudo. 
El primer tipo, frecuentemente representado en el mosaico de la Carta de Madaba como edificaciones de estructura simple, provistas de dos torres en los ángulos y puerta arqueada o rectangular (figuras 2-3), algunas anepigrafas y otras identificadas por las inscripciones que los acompañan con los topónimos Agbaron, Arad, Asemona, Bethagidea. Coreus, Gerara, Gofna, Mampsis, Minois, Seana, Sicomazon, sigue el modelo simplificado de las villae con torres figuradas en los mosaicos tardorromanos especialmente de Hispania y del $\mathrm{N}$. de África ${ }^{6}$, y se repite en la Tabula Peutingeriana, datada en el siglo $\mathrm{V}$, donde el modelo se ha utilizado, como en el pavimento de Madaba, para las representaciones sintéticas de ciudades ${ }^{7}$. En

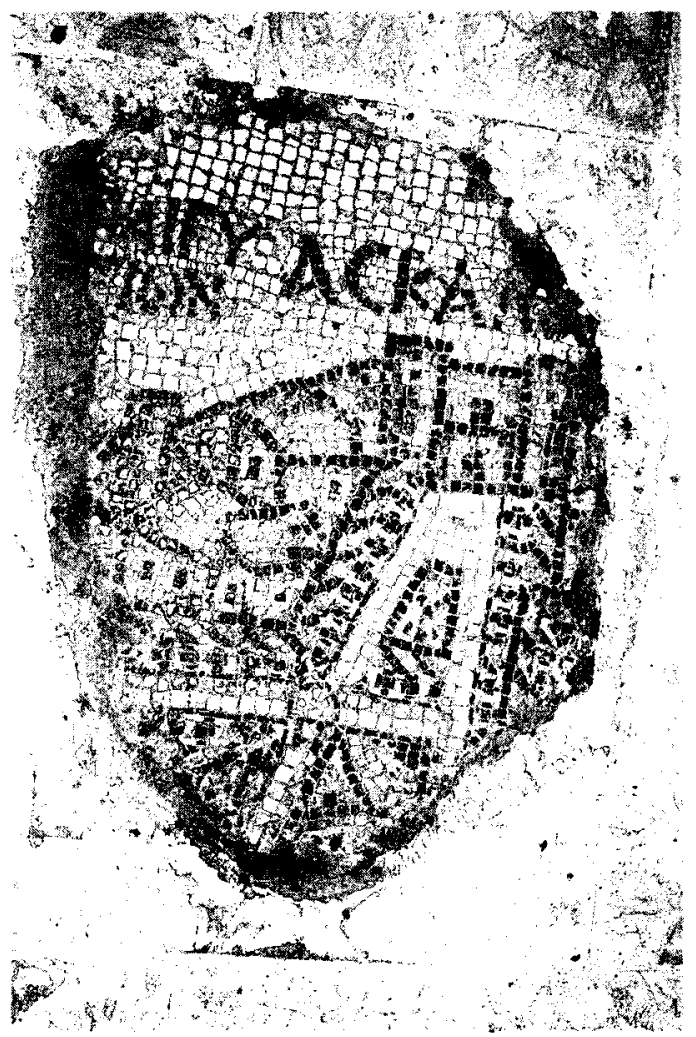

Figura 4. Mosaico de Madaba. Askalón. Foto G. López Monteagudo.

M.P. San Nicolas Ph Dhaz. Arquitectura rural en los mosaicos hispanos. XII Convegno di Studi su l'Africa Romana (Olbia 1996). en prensa. Agradezco a la Dra. San Nicolás Pedraz el haberme permitido consultar y hacer uso de su trabajo.

K. Mil fF, Die Peutingersche Tafel, Stuttgart 1962; A. y M. Li VI, Itineraria Picta, Roma 1967 


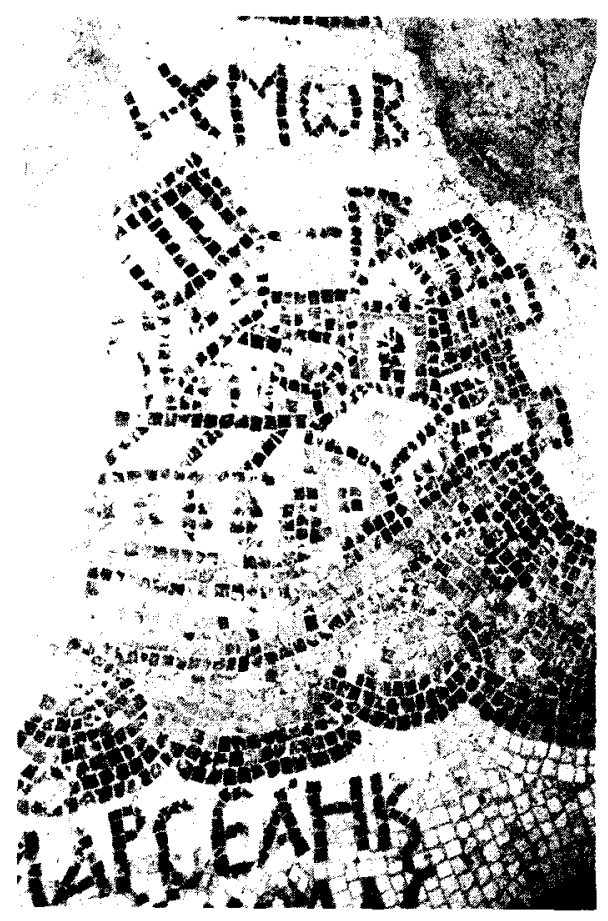

Figura 5. Mosaico de Madaba. Charach Moba. Foto G. López Monteagudo.

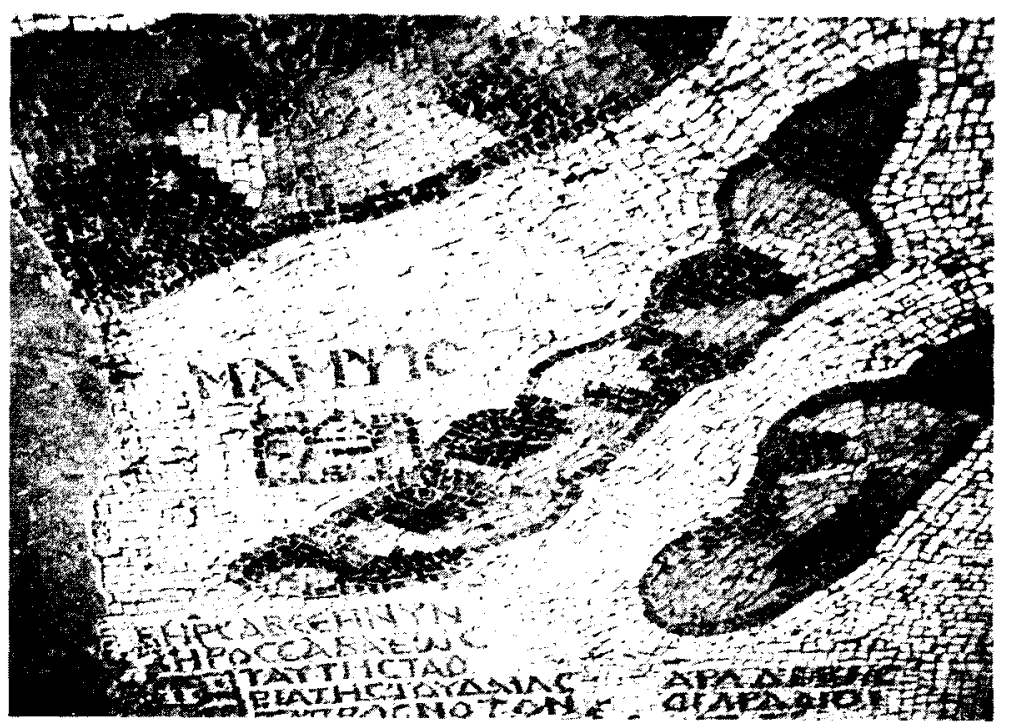

Figura 6. Mosaico de Madaba. Mampsis. Foto G. Lopez Monteaaudo 
Madaba la misma estructura sirve igualmente para figurar las puertas de las ciudades amuralladas (figuras 4-5), como Aia, Askalon, Charach Moba (aqui con la particularidad de que una de las torres hace al mismo tiempo de pared lateral de un edificio de frontón), Ekoue, Hagiapolis (Jerusalén), Tharais, Zoora. En algunos edificios de Madaba (figura 6) hay indicación también de un cuerpo central (Mampsis, Praesidium, Thamara), caracteristica que igualmente se documenta en ciertas villae representadas en los mosaicos tardorromanos de Arróniz (compartimentos II y IV) ${ }^{8}$, Constantina y Tabarka ${ }^{9}$, aludiendo al oecus o sala de recepción. El tipo simplificado y esquemático de villa romana de torres sufre en la Carta de Madaba una nueva interpretación en las ciudades de Aia, Archelais, Betsura. Elusa, lethor, Jericho Orda, Photis, Safitha, Rinocorura y Zoora, que aparecen representadas mediante un conjunto de torres de tejado plano, unidas por un muro y acompañadas en el caso de Jericó y Zoora de varias palmeras (figuras 7-8), complemento paisajístico que también se documenta en las villae figuradas en los mosaicos romanos. En ocasiones es posible distinguir, en un segundo plano, los tejados de los edificios en el interior de los recintos amurallados.

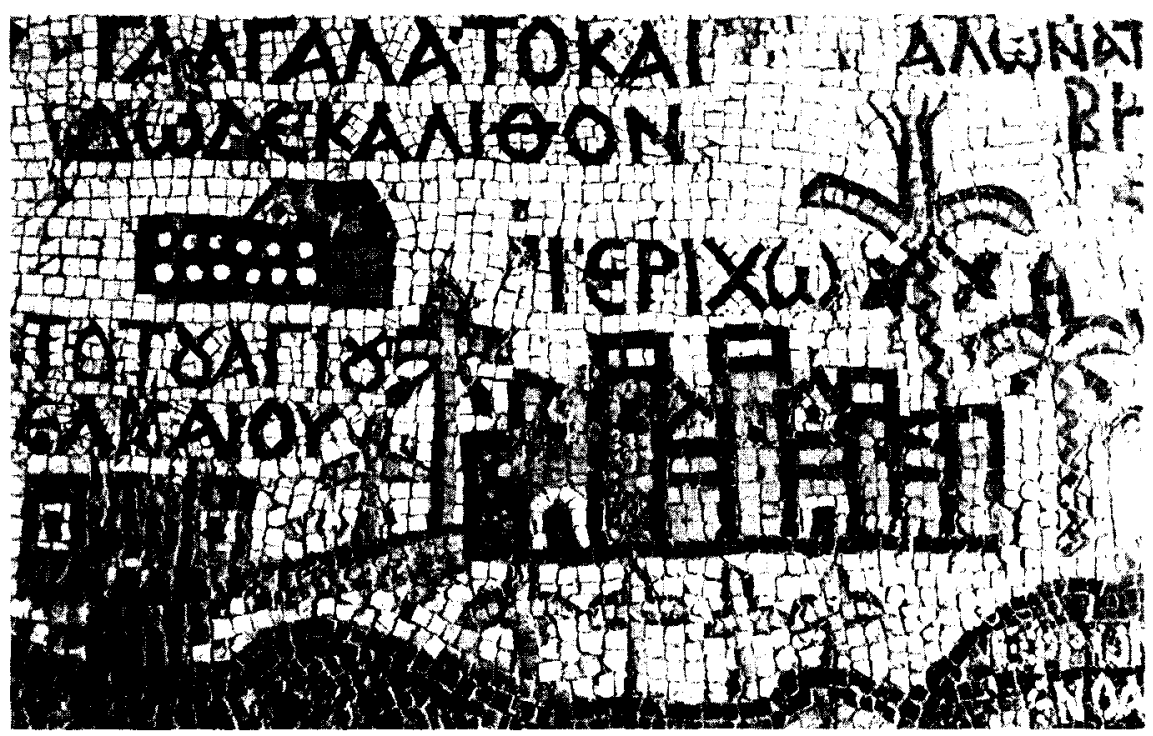

Figura 7. Mosaico de Madaba. Jericó y San Eliseo. Foto G. López Monteagudo.

CMRE VII, 1985, láms. 13,16 y $51-52$

K.M.D. Dunbahin. The Mosaics of Roman North Africa, Oxford 1978, pl. 34 y 111; T. SariNowski. La representation de villas sur les mosaïques africaines. Varsovia 1978, figs, 5, 8-9. 

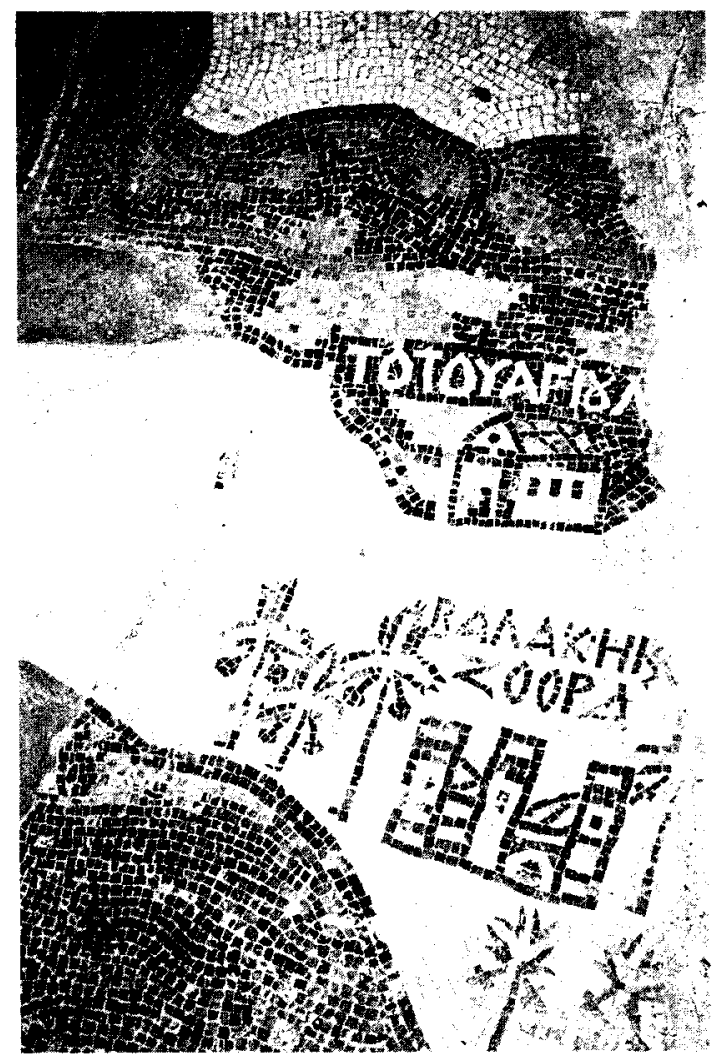

Figura 8. Mosaico de Madaba. Zoora y San Lot. Foto G. López Monteagudo.

Villae de torres se representaron en varios compartimentos del mosaico octogonal de las Musas de Arróniz, conservado en el Museo Arqueológico Nacional de Madrid, que se fecha a fines del siglo III o a comienzos de IV ${ }^{10}$. Los edificios que aparecen en los sectores I y VI (figura 9) están formados por tres cuerpos: el central, de forma rectangular, se ha construido a base de grandes y desproporcionados bloques y presenta una gran puerta arqueada de acceso; los dos laterales están constituidos por sendas torres cuadrangulares de muros lisos y tejado a dos aguas, o circulares con cubierta cónica, apreciándose las ventanas que indican la existencia de varios pisos ${ }^{11}$. Se trata de una representación simplificada de 


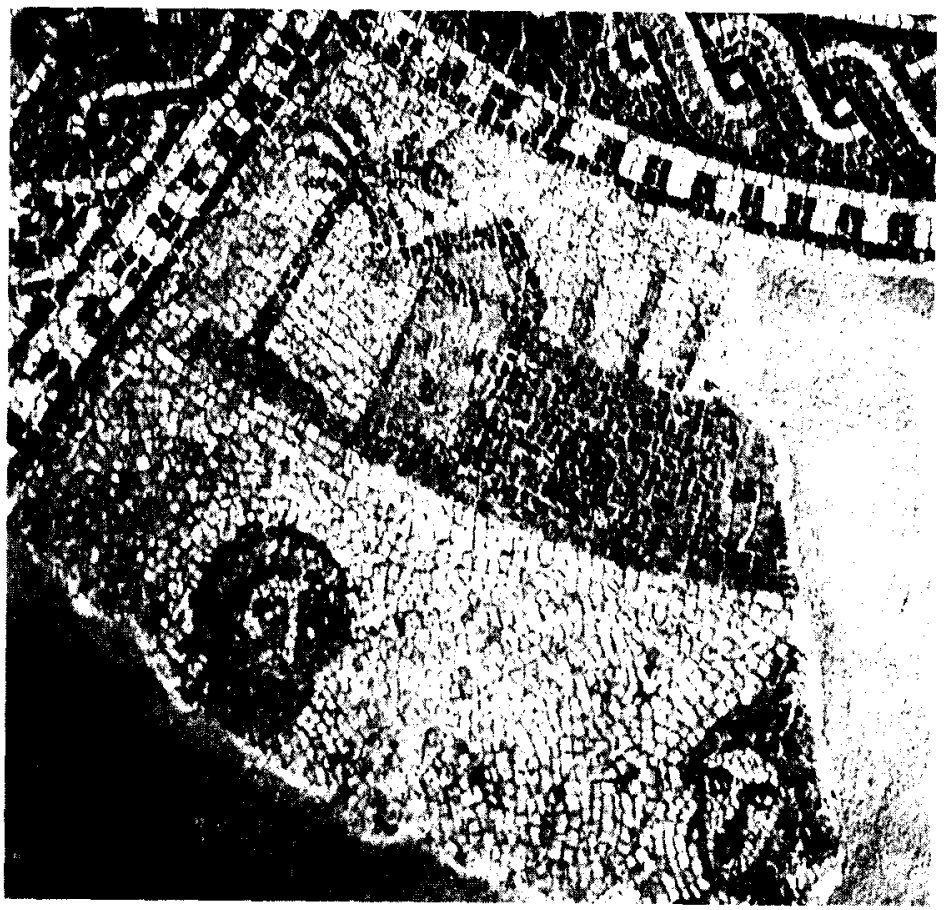

Figura 9. Mosaico de Arróniz. Compartimento I.

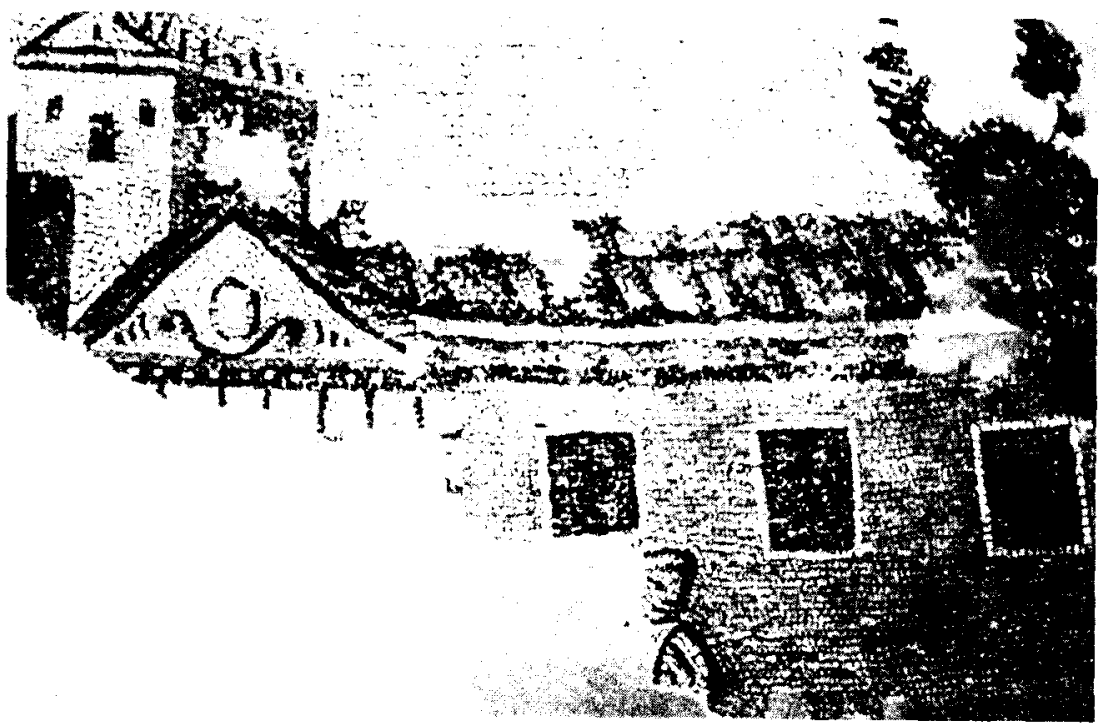

Figura 10. Mosaico de Centcelles. Villa rústica. Foto G. López Monteagudo. 
villa con torres, del tipo de la figurada en el mosaico tunecino de Thina, cuyo modelo iconográfico se atestigua igualmente en el plato de plata de Tebas, del siglo $\mathrm{IV}^{12}$.

El mismo tipo de edificio se documenta en el mosaico parietal que adorna la cúpula del mausoleo hispano-romano de Centcelles (Constantí, Tarragona), datado a mediados del siglo iv (figura 10) ${ }^{13}$. Se trata de la representación de una villa rústica, vista en perspectiva angular dentro de un mismo plano, como ocurre con el edificio que aparece en el compartimento VI de Arróniz. El muro lateral ofrece tres ventanas, mientras que en la fachada principal, muy deteriorada, se aprecia el frontón de la puerta de acceso, una ventana y restos del muro; detrás puede verse la torre rectangular con tejado a doble vertiente y tres ventanas del piso superior. Esta parcial representación tiene un paralelo muy próximo en el topónimo Agbaron de la carta de Madaba (figura 11).

Las puertas arqueadas, abiertas en los muros y edificaciones de las villae representadas en los mosaicos hispanos citados, así como en uno de los semicírculos del pavimento de los peces de La Vega Baja de Toledo,

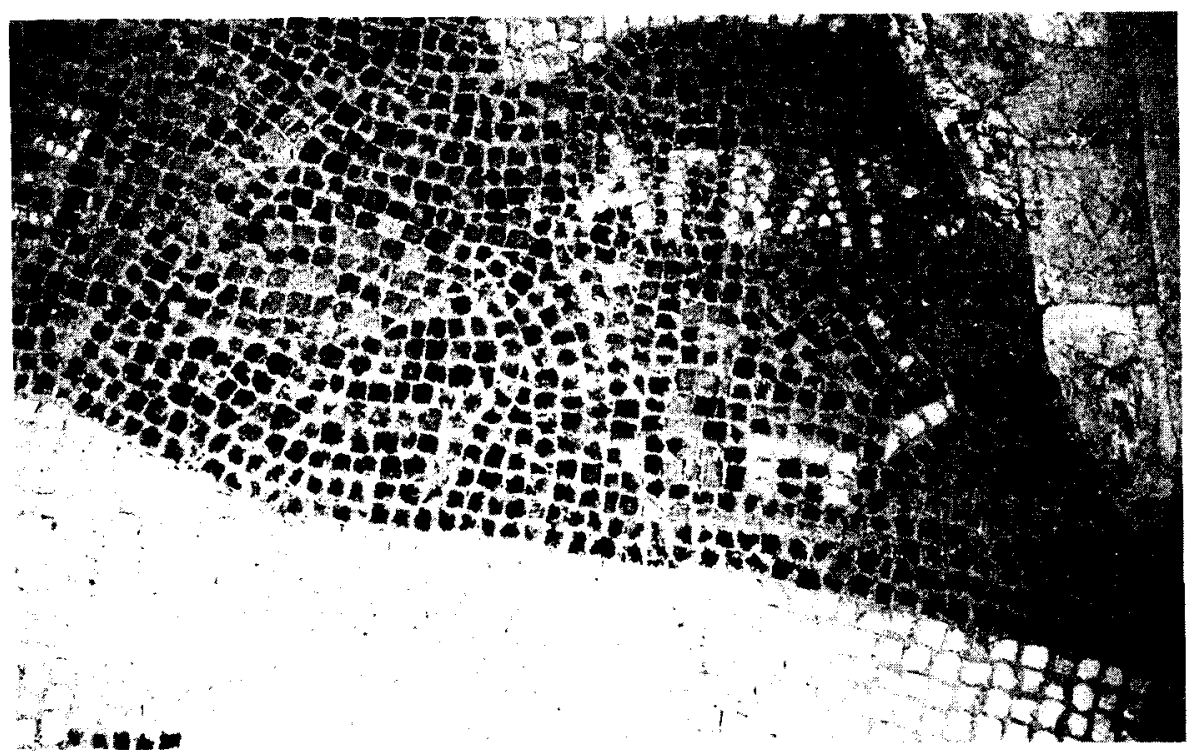

Figura 11. Mosaico de Madaba. Agbarón. Foto G. López Monteagudo.

T. SARnowski, La représentation de villas sur les mosaiques africaines, Varsovia 1978, págs. 54-85. figs 10,68 .

H. Schlunk. Die Mosaikkuppel von Centcelles, Mainz 1988. págs 111-112. Abb. 45a y 46b. Taf. 12. 
que se fecha a comienzos del siglo IV d.C. ${ }^{14}$, y en el fragmento musivo procedente de El Reguer (Puigvert de Agramunt, Lérida), datado en el último cuarto del siglo ${ }^{15}$, se documentan en numerosos pavimentos norteafricanos de los siglos III y IV, como Hippo Regius, Tabarka o Constantina, en el edificio principal del mosaico de las labores agrícolas de Oudna, fechado a mediados del siglo II, que es de forma rectangular, con ventanas en la parte superior y tejado a doble vertiente, así como en la villa del dominus lulius de Cartago, ca. 380-400, a la que se entra por un gran portal arqueado, a través del cual se accede a los edificios, uno de forma rectangular con tejado a doble vertiente, y otro integrado por varios cuerpos circulares abovedados, seguramente las termas ${ }^{16}$. En el mosaico de la Carta de Madaba se documentan puertas arqueadas en las edificaciones de las ciudades de Asemona, Coreus, Ostracine, Sicomazon, Tecoe, entre otras, y también en las representaciones de Aia, Askalon, Jericho, Hagiapolis y Zoora, con puertas arqueadas abiertas en la muralla como es habitual. En el Oriente se documenta el mismo tipo de puerta arqueada en un edificio representado en la franja que bordeaba un pavimento destruido, descubierto en el sector 11-P del Yakto Complex de Antioquía (figura 12), del mismo tipo que el borde del

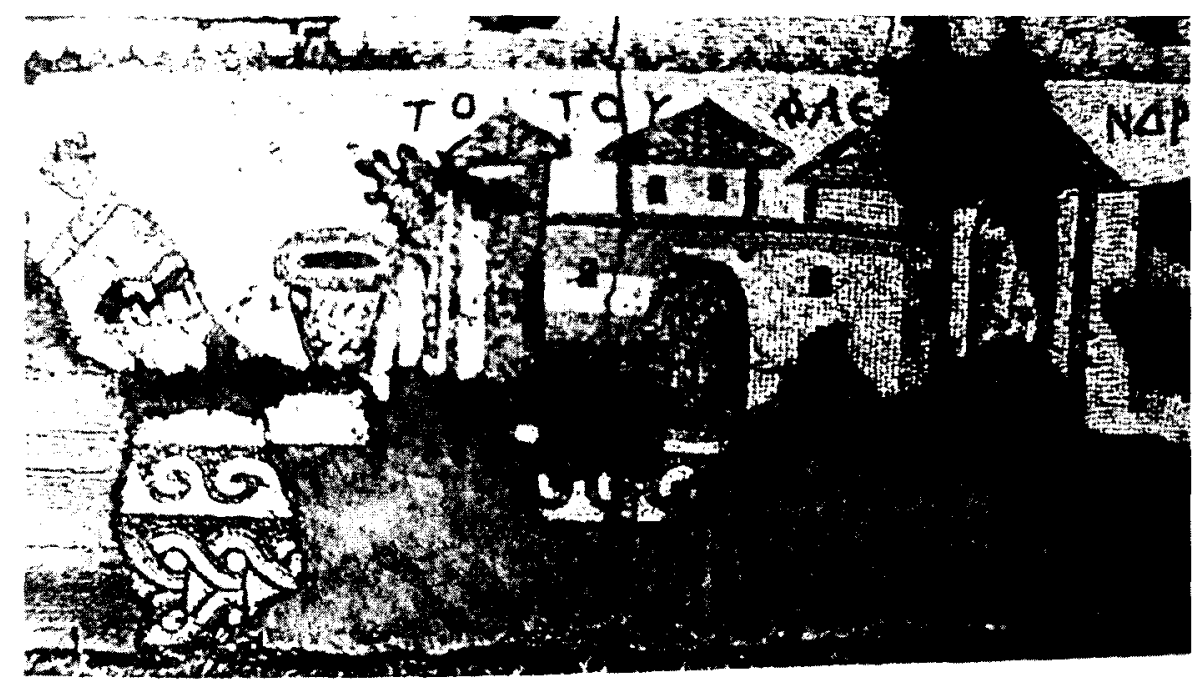

Figura 12. Mosaico de Antioquia. Yakto Complex, sector 11-P.

CMRE V, 1982, págs. 36-40, no 26, láms. 22 y 47.

CMRE IX, 1989, págs. 21-23. no 21, lám. 9.

K.M.D. Dunsiabin, The Mosaics of Roman North Africa, Oxford 1978, págs. 252, 255, 262. 265 y $271, \mathrm{pl} .34,101,109,112$ y 123. 
mosaico de la Megalopsiquia, datado en época constantiniana ${ }^{17}$. El edificio, al que acompaña la inscripcion griega Alexandrenou, presenta una alta valla en cuya parte central se abre un gran vano arqueado flanqueado por dos pequeñas ventanas en la parte alta; otra puerta arqueada de mayor tamaño se abre en el frente de una gran construcción rectangular, flanqueada por otros dos edificios menores también rectangulares, con ventanas en la parte alta y techo a doble vertiente, del mismo tipo que la torre de la muralla, por el que sale un personaje como en el citado mosaico de Oudna.

Las puertas arqueadas son frecuentes en las imágenes de ciudades y de edificios en otros pavimentos bizantinos, baste recordar algunos ejemplos, como la ciudad de Sidón en el mosaico sirio del Rapto de Europa, procedente de Sarrîn, que se data entre fines del siglo $\vee$ y mediados del vI ${ }^{18}$; la ciudad de Egipto figurada en el pavimento palestino de Haditha, de la segunda mitad del siglo vi ${ }^{19}$; las ciudades de Alejandría, Canopo,

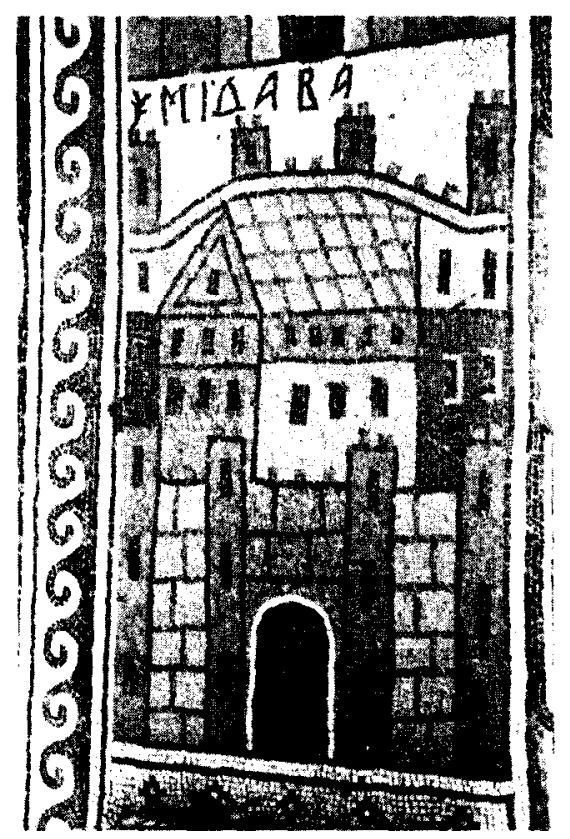

Figura 13. Mosaico de Umm al-Rasas, iglesia de San Esteban. Madaba.

Foto G. López Monteagudo.

D. LŁvI, Antioch Mosaic Pavements, Princeton 1947, págs. 345-346. pl. LXXIV b-c.

J. Balir, La mosaïque de Sarrin (Oshoène), Paris 1990. págs. 49-50. pl. XXI,1.

R. A. Ovadiah, Mosaic Pavements in Israel. Roma 1987. No. 86. pl. LXIV.2. procedente seguramente de una iglesia. 


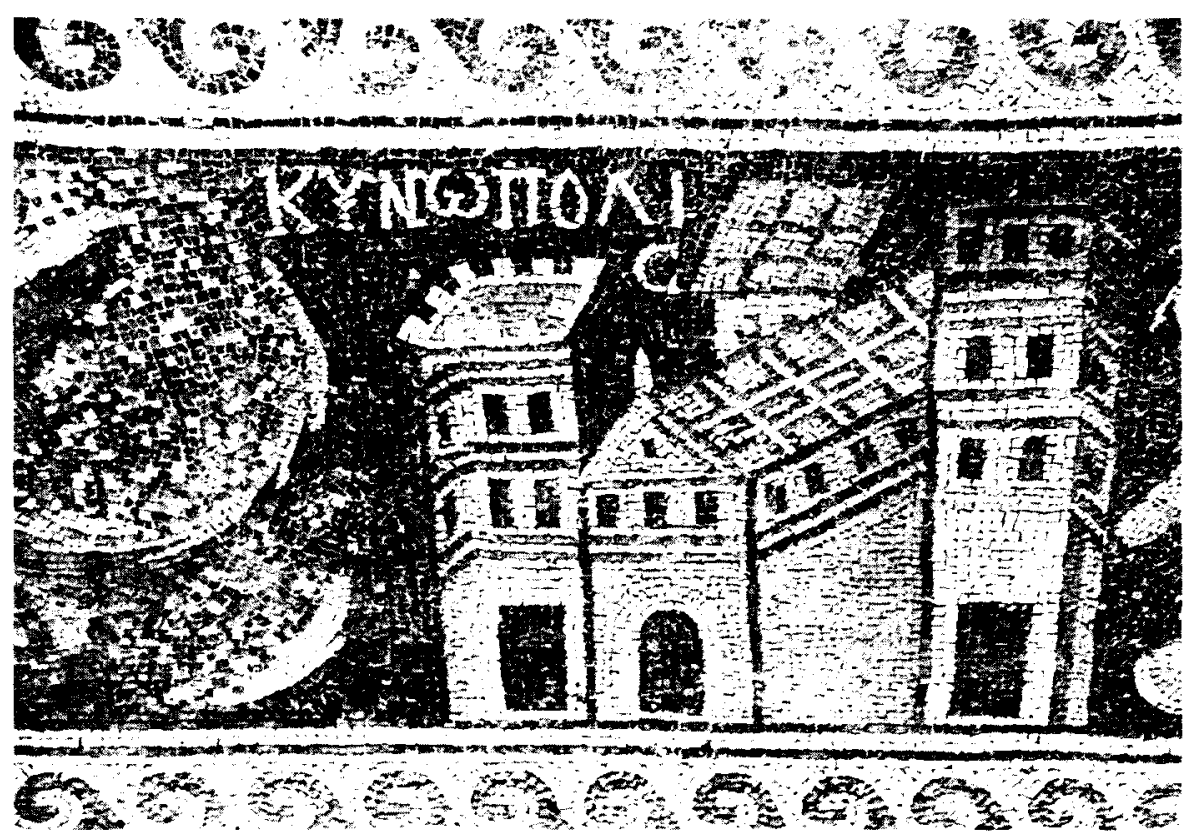

Figura 14. Mosaico de Umm al-Rasas, iglesia de San Esteban. Kinópolis. Foto G. López Monteagudo.

Menuti y Menfis, representadas en los pavimentos jordanos, de los siglos VI-VII, de Gerasa y Khirbat al-Samra ${ }^{20}$; así como en Umm al-Rasas, en los mosaicos de las iglesias de los Leones (representación de Kastron Mefa) y de S. Esteban (ciudades de Filadelfia, Madaba, Jerusalén Cesarea, Askalón, Gaza, Pilousin, Pseudostomon y Kinopolis), que se fechan ya en los siglos VI y VIII, respectivamente (figuras 13-14) ${ }^{21}$.

Otro tipo de construcción, en este caso porticada, que se ha figurado en el mosaico de Madaba, puede ponerse en relación con el tipo de villa denominada de galería o loggia, frecuentemente representada en la musivaria romana. Una arquitectura formada por galería o loggia, cuerpo central cuadrangular de dos pisos y tejado a doble vertiente, y dos torres en los extremos, se representa en el mapa de Madaba bajo el topónimo Athribis, identificado con Tell Athrib, en Egipto (figura 15);

M. Piccifillo, The Mosaics of Jordan. Amman 1993, págs. 273-4, 288-9, 292, 302-4, pl. $504-5,542-3,545,556,592$ y 596.

M. Piccifil i. o-E. Alliata, Umm Al-Rasas. Mayfa'ah. I. Gli scavi del complesso di Santo Stefano, Jerusalem 1994, láms. II, IV, V, X, XIII, XVI. XVII, XIX y XXII. 


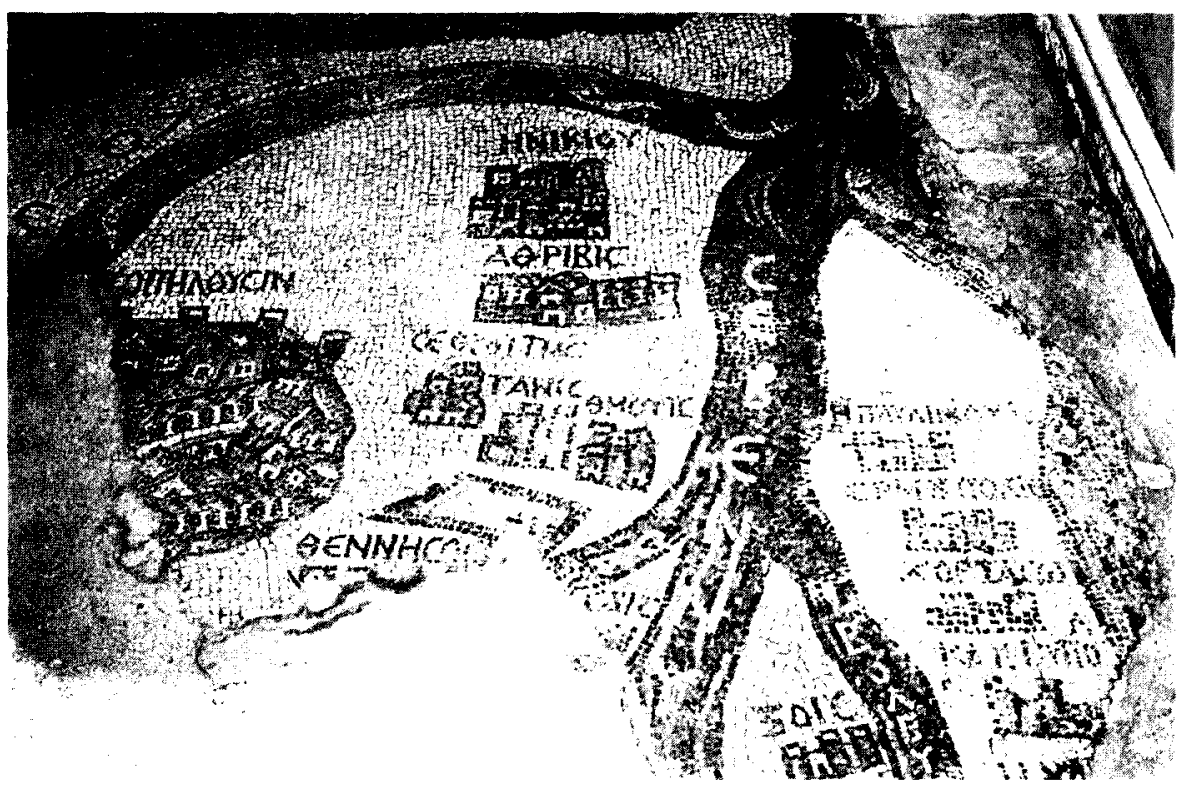

Figura 15. Mosaico de Madaba. Athribis. Nicias y Pilousin. Foto G. López Monteagudo.

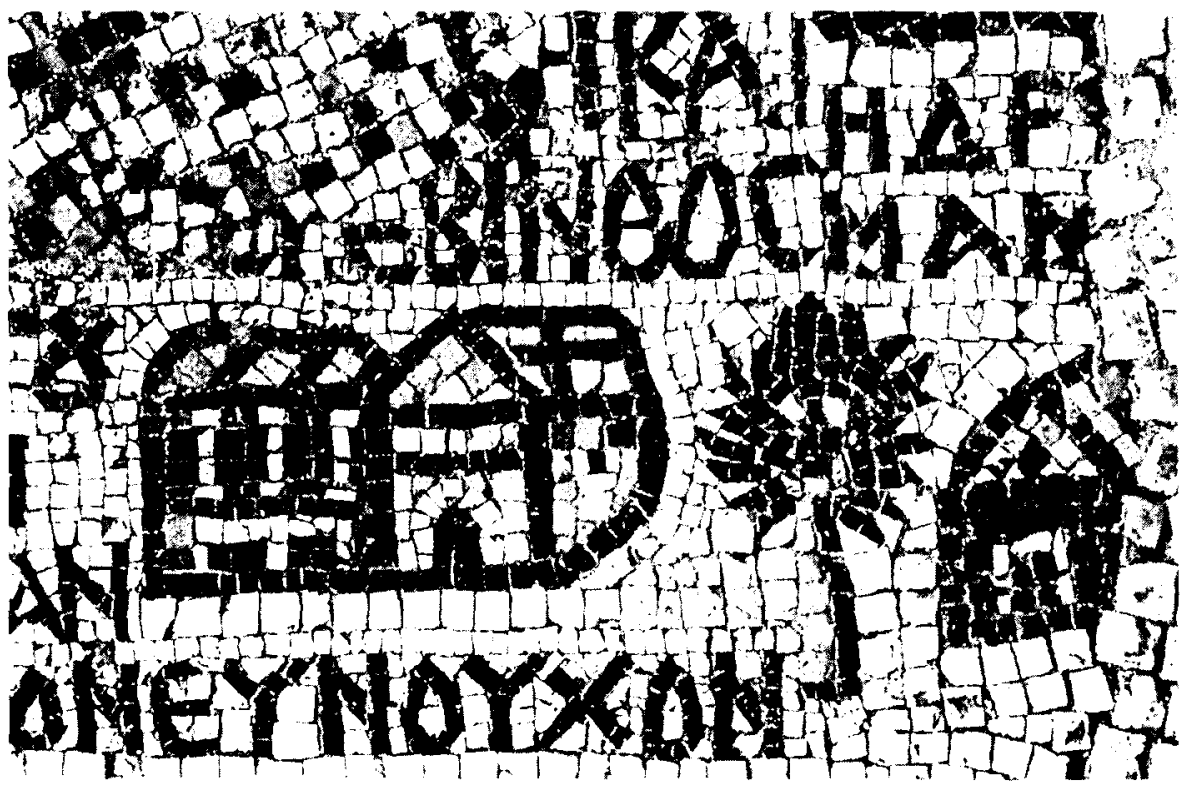

Figura 16. Mosaico de Madaba. Terebinto. Foto G. Lopez Monteagudo. 
también el lugar denominado Terebinto, identificado con Hebrón (figura 16), consta de dos cuerpos de edificio, una galeria porticada de tres columnas que sostienen un tejado inclinado, y un edificio con frontón y cubierta a doble vertiente, del que se ve la fachada principal con puerta arqueada y un lateral con ventana cuadrada; una tercera construcción porticada (figura 5) forma parte de la ciudad de Charach Moba. Otras arquitecturas porticadas, aparte de las calles figuradas (figuras 4, 32 y 36) en las viñetas de Askalón. Gaza y Hagiapolis, se representan en la carta de Madaba bajo los topónimos de Azotos Paralos, Diospolis, Gaza, Nicias, Pilousin y el lugar de San Victor (figuras 15, 31, 32, 36 y 37).

El tipo de villa de galería o loggia y dos torres en la fachada se ha representado en varios compartimentos del mosaico de Arróniz (figura 17) ${ }^{22}$. En el II aparece una construcción provista de loggia o galería enrejada, situada en la parte inferior, formada por seis columnas que sostienen una techumbre plana, sobresaliendo por detrás tres construcciones cuadrangulares con tejado a doble vertiente. Por la forma en la que está representado este edificio es dificil afirmar que se trata de una villa de galería y dos

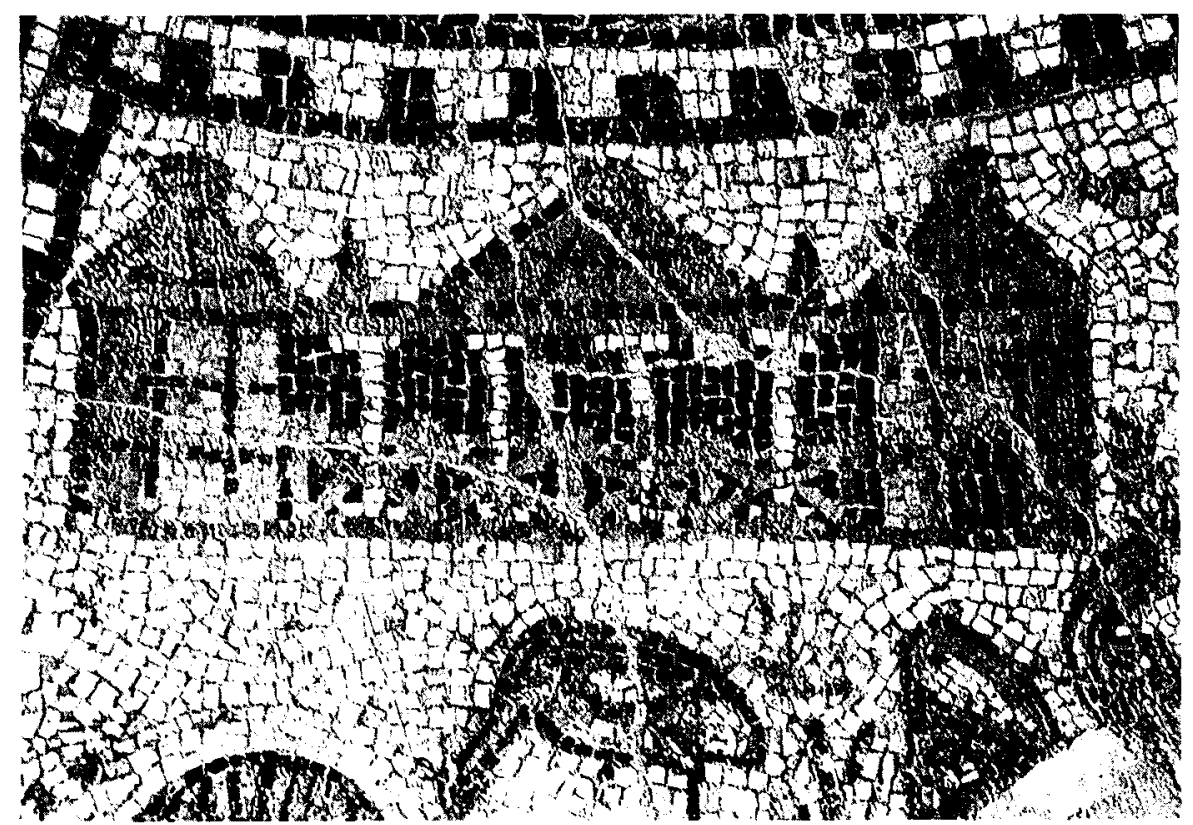

Figura 17. Mosaico de Arróniz. Compartimento IV. Foto G. López Monteagudo. 
torres con una construcción detrás correspondiente al oecus, al igual que ocurre en los pavimentos norteafricanos de Constantina y de Tabarka ${ }^{23}$. La duda se disipa totalmente en el edificio representado en el compartimento IV, en el que se aprecia con toda claridad una construcción con fachada de galeria enrejada y dos torres cuadrangulares o circulares en los extremos, realizadas con grandes sillares y cubierta al parecer cónica, abriéndose en una de ellas la puerta de acceso arqueada. La galería está formada por cuatro columnas que sostienen la techumbre plana y por detrás se levanta el cuerpo central correspondiente a la sala de recepción de la villa. Una variante de este tipo de construcción se halla representada en el compartimento $\mathrm{V}$, aunque aquí falta parte de la zona izquierda y la construcción central, presentando la única torre que se ha conservado una puerta cuadrada y dos ventanas también cuadradas en el piso superior. Las tres columnas que restan sostienen un tejado inclinado. El modelo arquitectónico de villa de galería o loggia parece haberse figurado en el fragmento que, actualmente se halla situado en el círculo central del pavimento, pero que debe provenir del compartimento III, que se encuentra muy deteriorado. Del mismo tipo parece ser el edificio representado en el compartimento VIII, en el que se ven dos edificios cuadrangulares, con puertas rectangulares y tejado a doble vertiente, uno de ellos realizado con sillares de gran tamaño, unidos por una galería enrejada de tres columnas que sostienen también una techumbre inclinada, así como la villa del compartimento IX, muy deteriorada, de la que solo se conserva la parte inferior, pudiéndose apreciar la galería enrejada.

La misma estructura se documenta en el mosaico hispano llamado de los peces, procedente del peristilo de la villa romana de La Vega Baja de Toledo (figura 34) ${ }^{24}$. Las construcciones que aparecen en tres cuadros semicirculares constituyen, no un elemento secundario como es habitual en otros mosaicos de época romana, sino el tema principal, como ocurre en los mosaicos norteafricanos de Tabarka y Neápolis, en los mapas topográficos del tipo de la Tabula Peutingeriana y en los mosaicos bizantinos de Jordania. En uno de los semicírculos se ha representado un edificio residencial de corredor o galeria, dos torres en los extremos de la fachada y peristilo semicircular porticado. La galería de la fachada está formada por ocho columnas sobre estilobato, igual que las once que forman el peristilo. Las torres presentan dos pisos y puerta de

K.M.D. Dunbabin, The Mosaics of Roman North Africa, Oxford 1978, pl. 34 y 111: T. SaRNowski, La représentation de villas sur les mosaiques africaines, Varsovia 1978, figs, 5, 8-9.

CMRE V, 1982. láms. 20 y 47. 
acceso en forma de $T$, y se cubren con tejado a doble vertiente. Una especie de galería porticada, a no ser que se trate de una escalera, se representó también, delante de un gran arcada con cortina recogida a un lado, en el mosaico hispano procedente de la villa romana de El Reguer ${ }^{25}$, cuyos paralelos más próximos se encuentran en la representación de la ciudad de Alejandría en el mosaico de la iglesia de San Juan Bautista de Gerasa ${ }^{26}$.

Arquitecturas porticadas se documentan asimismo, entre otros, en los pavimentos africanos de dominus lulius de Cartago, Tabarka, El Alia, Sousse, Hippo Regius y Neápolis ${ }^{27}$, en el mosaico de Océanos de Bad Kreuznach, de mediados del siglo $111^{28}$, en el itálico de Oderzo que se

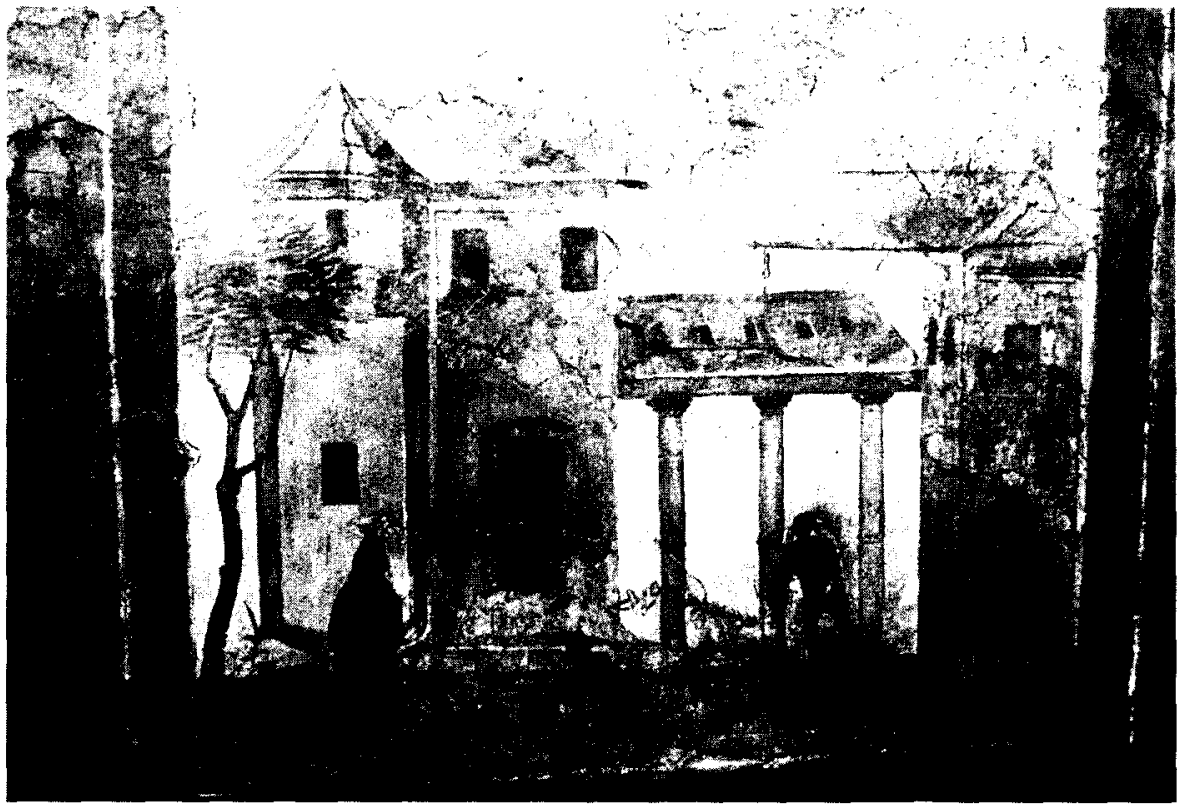

Figura 18. Pintura de Tréveris. Villa rústica. Foto G. López Monteagudo.

CMRE IX, 1989, págs. 21-23, n²1, lám. 9.

M. PlCCIRILI o, I Mosaici di Giordania, Roma 1986, Cat. 2.

T. SaRNowskt, La représentation de villas sur les mosaïques africaines, Varsovia 1978. págs 54-85, figs. 2, $31-32$ y 37; K.M.D. Dunbabin. The Mosaics of Roman North Africa, Oxford 1978, pag. 262, pl. 109 y 123. J.P. DARMON. Nympharum domus. Les pavements de la maison des Nymphes à Neapolis (Nabeul. Tunisie) et leur lecture, Leyden 1980. págs. 103104. pl. LI.

is G. Rupprechi, Römische Steinteppiche. Die Mosaikböden der Peristylvilla in Bad Kreuznach. ArchDeutschland 3, 1989, págs. 18.21. 


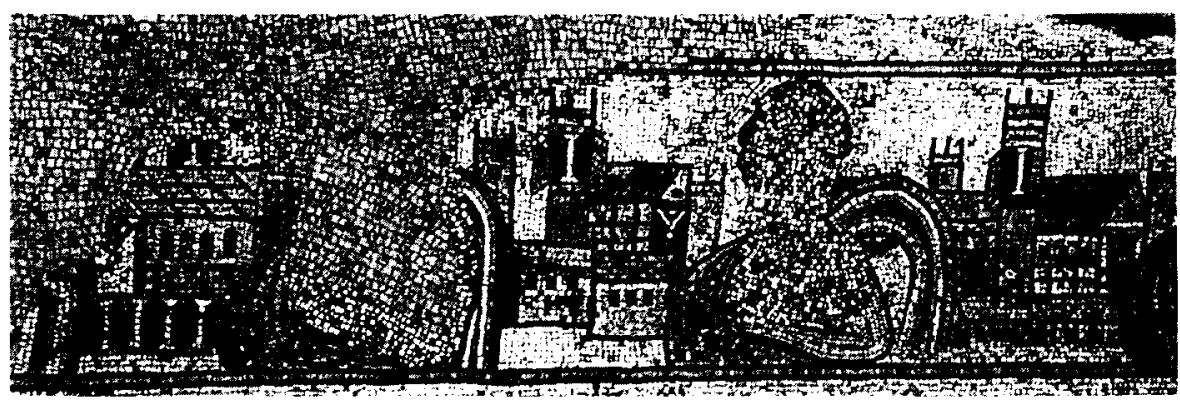

Figura 19. Mosaico de Umm al-Rasas, iglesia del Padre We'il.

fecha en el siglo IV ${ }^{29}$, en los paneles vidriados de Kencherai, datados hacia 350 d.C. ${ }^{30}$, o también en la orla de la Megalopsiquia de Antioquía ${ }^{31}$ y en una pintura de Tréveris (figura 18) ${ }^{32}$, y perduran en los edificios representados en los pavimentos bizantinos de los sigios $V$ - $V$ I, procedentes de la casa de Leontius en Beth-Shean ${ }^{33}$, y de las iglesias del Padre We'il en Umm al-Rasas (figura 19), de S. Juan Bautista y de S. Pedro y $S$. Pablo, en Gerasa ${ }^{34}$, y aún a comienzos del siglo vili en los mosaicos de la Gran Mezquita de Damasco (figura 20), en donde los edificios con sus pórticos, pabellones, techos puntiagudos y quioscos en los jardines recuerdan a las arquitecturas paisajísticas de las pinturas romanas del siglo I, o a las decoraciones teatrales del segundo estilo pompeyano y, sobre todo, a las villae de los mosaicos norteafricanos y a las imágenes topográficas de algunos pavimentos del siglo $v$ y $\vee$ d.C. de Siria y de Palestina, documentando la ósmosis de elementos sasánidas, greco-bizantinos y romanos existentes en los repertorios utilizados para su ejecución ${ }^{35}$.

L. Bratacchi, Ricomposizione del mosaico opitergino con villa rustica, Mosaique. Recueil d'Hommages à H. Stern. Paris 1983, págs. 65-73, pl. XLVI y CCXXXI.

L. IeraAtim et alii, Kencherai, II, Leiden 1976.

D. Lfvi. Antioch Mosaic Pavements. Princeton 1947, pl. LXXX.

R. Schindil F, Führer durch das Landesmuseum Trier. Trier 1980, pág. 53, Abb. 156.

R.-A. OvaljaH, Mosaic Pavement in Israel, Roma 1987, págs. 35-6, pl. XX-XXII.

M. Picciril 1 O. The Mosaics of Jordan, Amman 1993, págs. 243, 289 y 292, pl. 397, 542-3 y 556

E. DE Lofiey, L'Hellenisme et l'Orient dans les mosaiques de la Mosquée des Omeyades, Ars Islamica I. 1934; H. Lavacint., La mosaique, Paris 1987. págs. 95-97. Según H. Stern, las arquitecturas representadas en los mosaicos de la mezquita de Damasco no siguen modelos exactos basados en la realidad visual. sino que son como renuevos de decoraciones arquitectónicas antiguas. modificadas y aisladas de su contexto, en las que prima lo simbólico sobre lo real. A pesar de los estrechos paralelismos entre las arquitecturas paisajisticas de Damasco y las pinturas romanas del siglo । d.C.. los inventores del programa decorativo de Damasco no se inspirarian directamente en estos modelos tempranos, sino en obras más o menos contemporáneas, en imágenes topográficas en boga en Siria y Transjordania de los siglos $v$ y $\mathrm{v}$. como la orla de la Megalopsiquia de Antioquia, el mapa de Madaba, los pavimentos de Gerasa o de Ma'in. etc., a los que 


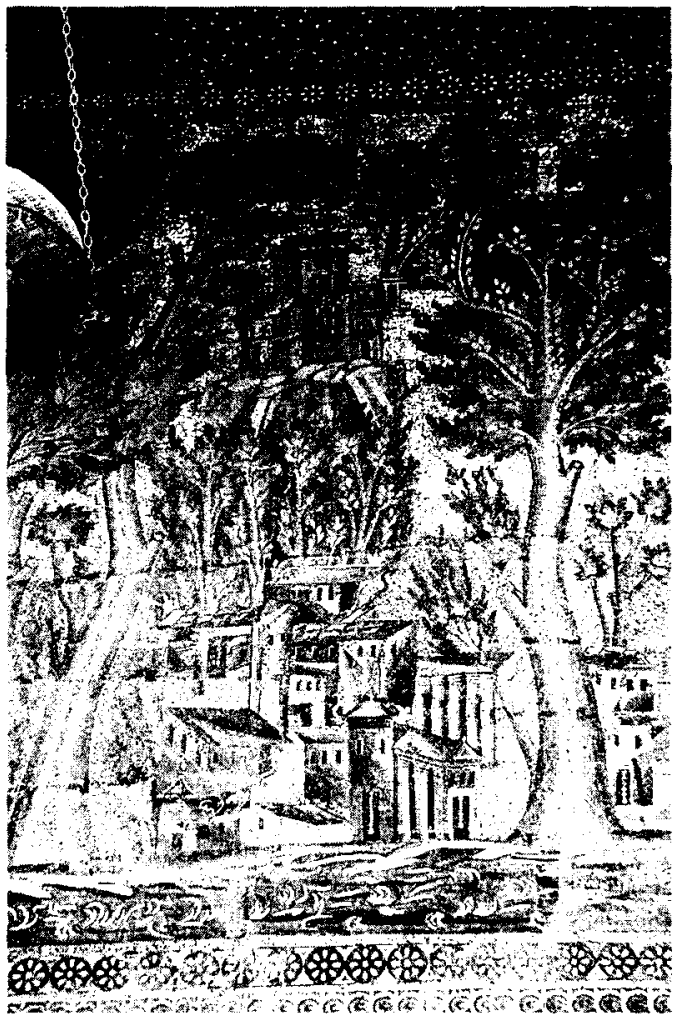

Figura 20. Mosaico de la Gran Mezquita de Damasco. Foto G. López Monteagudo.

Por otra parte, las construcciones semicirculares integradas por pórticos que enlazan distintos pabellones y torres circulares en los extremos, constituyen una de las características más sobresalientes de las villae maritimas, frecuentemente representadas en los mosaicos tardorromanos del $\mathrm{N}$. de África (Djemila, Cartago, Leptis Magna) y de Italia (Piazza Armerina, Sta. María in Trastévere) ${ }^{36}$. En la musivaria hispano-romana se ha figurado un edificio similar en el pavimento que ornaba el fondo de una fuente octogonal en la villa de la Vega Baja de Toledo, con una cronología a fines del siglo III o a co-

habria que añadir las pinturas contemporáneas que decoraban los muros de las iglesias, que no se han conservado pero de las que se tienen noticias por los textos, cf. H. STFRN, Notes sur les mosaïques du Dôme du Rocher et de la Mosquée de Damas, Cahiers Archeologiques XXII, 1972 , págs. 217-225.

35 G. LOPEz MONTEAGIJDO, Representaciones de ciudades en mosaicos romanos del Norte de Africa, L'Atrica Romana X (Oristano 1992), Sassari, 1994, págs. 1.241-1.257 
mienzos del IV ${ }^{37}$. En él se ha figurado un paisaje portuario de tipo alejandrino en el que destaca una gran construcción semicircular porticada, con torreones y columnas en los extremos, que tanto puede ser una villa marítima, como un edificio portuario del tipo de los documentados en pinturas pompeyanas ${ }^{38}$, en vidrios puteolanos de fines del siglo III o comienzos del IV ${ }^{39}$, en lucernas itálicas y norteafricanas fechadas entre 175-250 ${ }^{40}$, y también en monedas de Asia Menor del siglo III d.C. ${ }^{41}$. A este tipo de representaciones pertenecen igualmente los citados paneles de opus sectile en pasta vítrea (figura 21), ha-

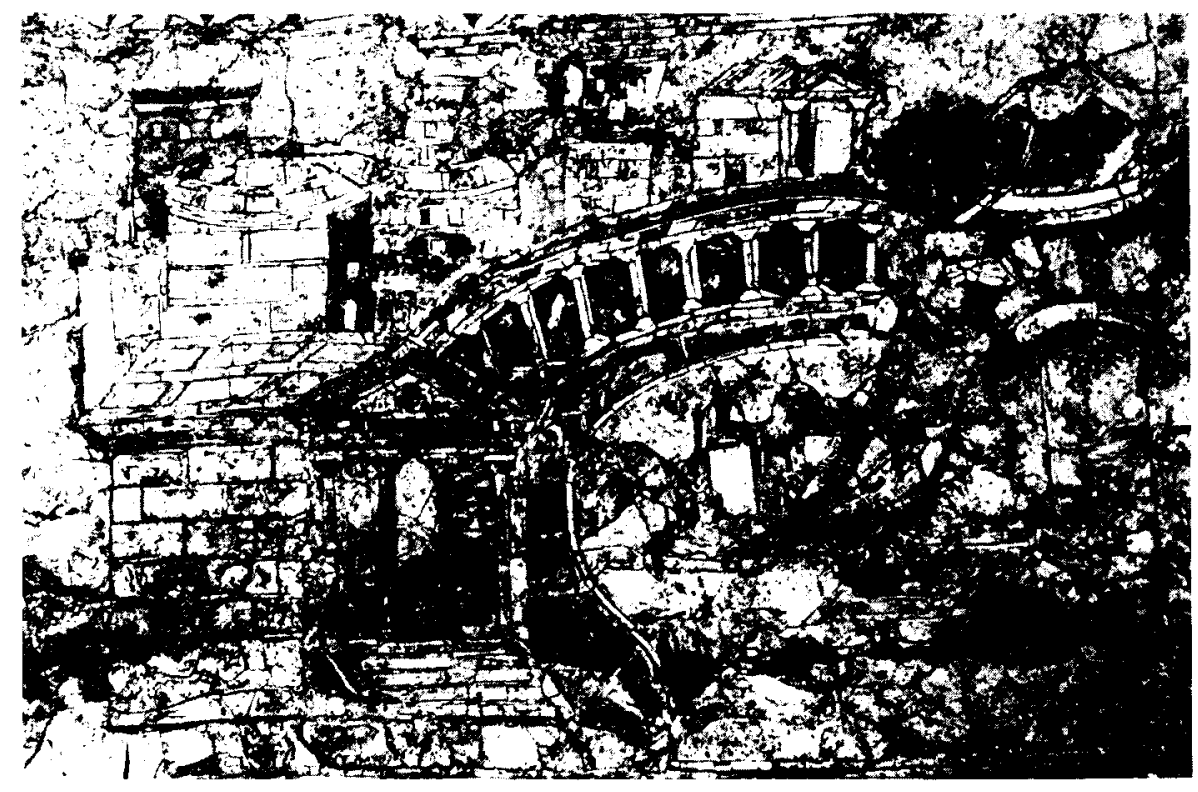

Figura 21. Panel vidriado de Kencherai.

CMRE V, Madrid 1982, págs. 33-36, n²5, láms. 16-19 y 46; A. BALIL, Monumentos alejandrinos y paisajes egipcios en un mosaico romano de Toledo (España), Studi in onore di Achille Adriani 3. Foma 1984, págs. 433-439, piensa que se trata de un paisaje alejandrino y fecha el mosaico, por sus paralelos con las lucernas africanas, a mediados del s. III; G. López MonteAGUdo, Representaciones de ciudades en mosaicos romanos del Norte de África, L'Africa Romana $X$ (Oristano 1992) Sassari 1994, págs. 1.242-1.257, Tavv. IX-XII.

R. LING, Roman Paintings. Cambridge 1991, págs. 142-149

A. Garcia $\vee$ Bellidio, El vaso puteolano de Ampurias, AEspA 27, 1954, págs. 212-226; Ch. PICARD. Pouzzoles et le paysage portuaire, Latomus 18, 1959. págs. 23-51.

M. Guafiluccl, Una nuova officina di lucernette romane: gli Aeoli, RM. 89, 1982, págs. 114 121, Taf. 54-56; J. DentAuve, Notes sur quelques lampes africaines du III siècle, Ant.Afr. 22 1986, pp.141-155, fig. 6-10; D.M. BAILEY, A catalogue of the Lamps in the British Museum, III, London 1988, Q 1715 y Q 3408.

K. LFif MANn-HARTI EBen. Die antiken Hafenanlagen des Mittelmeers. Wiebaden 1963, núms. 1, 2, 5, 9-11: P.R. Frankt, Kleinasien zür römerzeit, München 1968, núms. 8 ? 84 y 86 
llados en el puerto de Corinto, que se datan a mediados del siglo IV d.C. ${ }^{42}$, así como el cuadro $n^{\circ} 21$ del Vergilius Vaticanus 3225, fechado ya en el siglo $\mathrm{V}$ d.C., en el que se ha figurado el Portus Drepani, al que arriba Eneas (Aen. III, Vs. 707 ss.) ${ }^{43}$. El mismo modelo iconográfico se ha utilizado para figurar los puertos de Cartago y de Roma en este último documento y también en la Tabula Peutingeriana, de la misma fecha ${ }^{44}$.

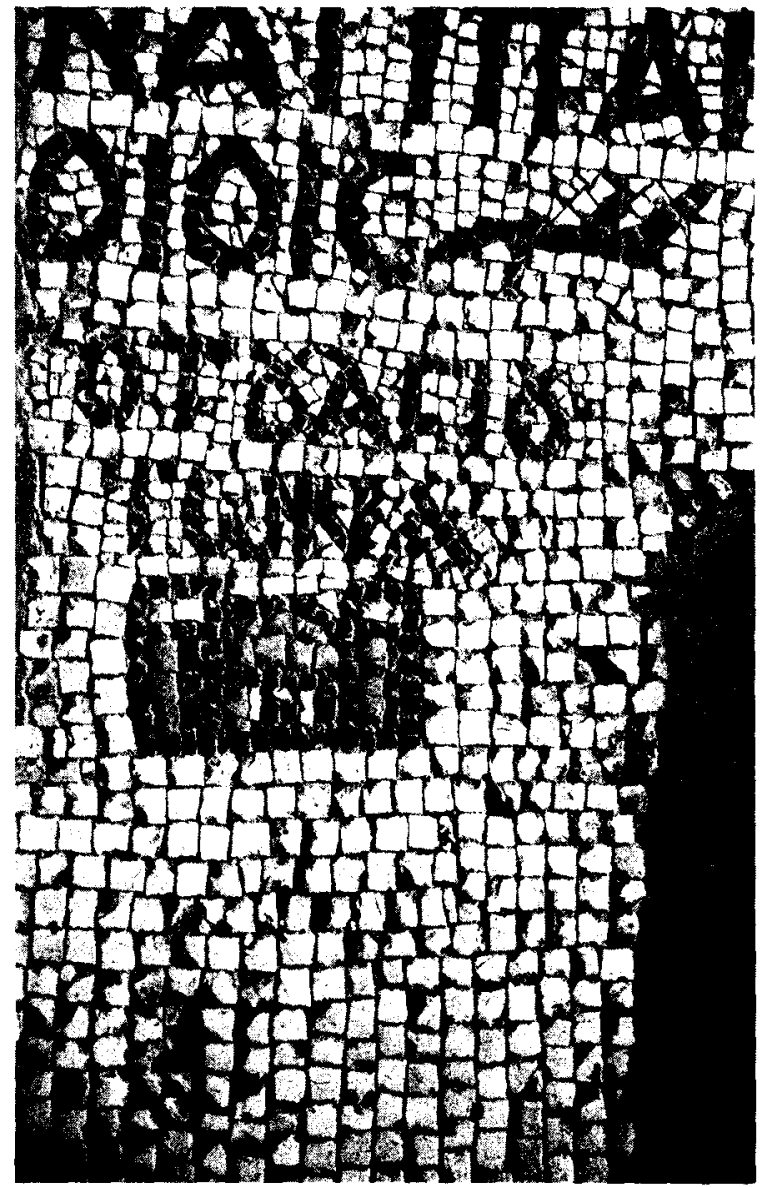

Figura 22. Mosaico de Madaba. San Jonás. Foto G. López Monteagudo.

\footnotetext{
4. L. IBrahim et alii, Kencherai. II, Leiden 1976, panel n 17 VI.5.A.

4.) J. DE: Wir i, Die Miniaturen des Vergilius Vaticanus, Amsterdam 1959. Taf. 13.1 y 31,1

44 K. MII LER, Die Peutingersche Tafel, Stuttgart 1962; A. y M. LFv।, Itineraria Picta, Roma 1967, seg. IV, 5 .
} 


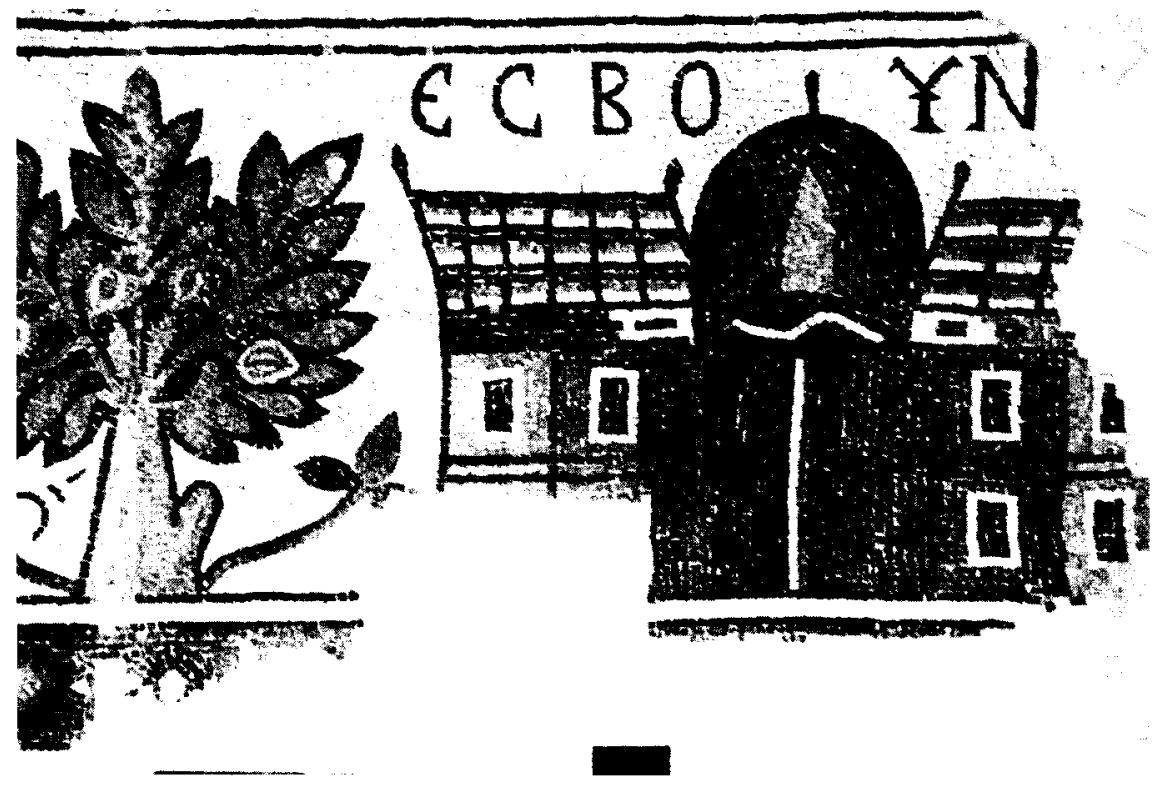

Figura 23. Mosaico de Main. Esbounta. Foto G. López Monteagudo.

En el mosaico de la Carta de Madaba, bajo los topónimos de lugar de San Eliseo y lugar de San Jonás (figuras 7 y 22), se ha representado una estructura abovedada o absidada entre dos torres de cubierta plana, como en las ciudades de Areopolis, Esbounta y Maiumas figuradas en la orla del pavimento de Ma'in (figura 23) ${ }^{45}$. Otro edificio, esta vez integrado por tres cuerpos abovedados, que recuerda las estructuras termales en los mosaicos romanos (Hippo Regius, dominus lulius de Cartago, Sidi Abdallah, orla de la Megalopsiquia de Antioquía) ${ }^{46}$, e identificado también como Maiumas, aparece en el mapa de Madaba (figura 24). La forma de desarrollar las fachadas de los edificios en perspectiva "aplanada" o alzados "desplegados", utilizada en la representación de estos lugares y también en la ciudad de Sicomazon y en el edificio del Santo Sepulcro de Jerusalén (figura 36), es típica del arte del Bajo Imperio, documentándose en numerosas representaciones de mosaicos, frescos y platos de plata, como el llamado "de la villa marítima» de Augusta Raurica ${ }^{47}$. Las características

\footnotetext{
4. M. Picciflllo, Madaba. Le chiese e i mosaici, Milano 1989, págs. 232-233

$\therefore$ G. Lopez Monteagudoo. Termas y tecnologia de las aguas. Testimonios musivos, Termalismo Antiguo. I Congreso Peninsular, Madrid, 1997, págs. 454-6. Figs. 2-6.

N. DUval, L'architecture sur le plat en argent dit "à la villa maritime" de Kaıseraugst (première moitié du IV siècle: un essai d'interprétation). Bulletin Monumental 146 IV. 1988 págs. 341-353.
} 


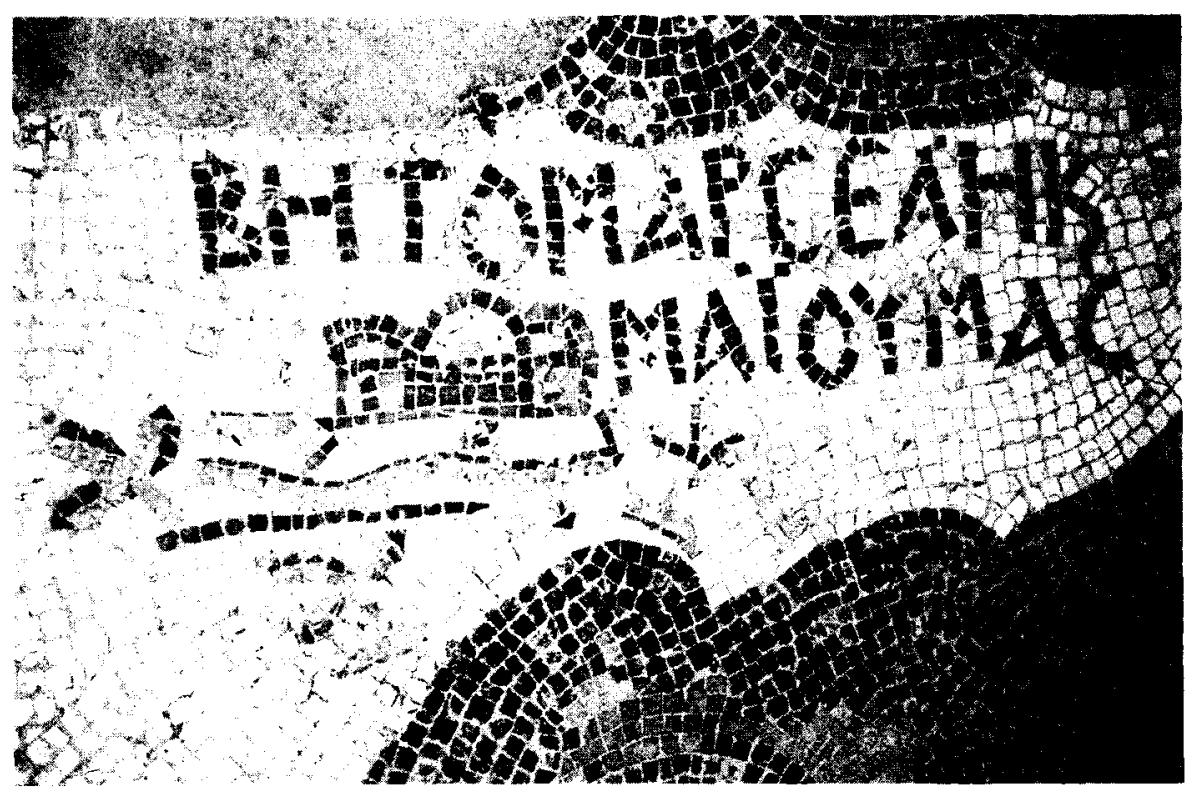

Figura 24. Mosaico de Madaba. Maiumas. Foto G. López Monteagudo.

principales de todas estas edificaciones, típicas del arte tardo-romano, es el carácter sintético y la falta de proporción en los edificios, utilizándose generalmente la perspectiva aplanada en donde en un mismo plano se unen y se superponen los diferentes elementos del edificio, como la fachada, las torres, los muros laterales y el peristilo.

El modelo de edificio simétrico, que comporta un elemento central y eventualmente dos elementos laterales reunidos por pórticos o muros, alcanza un gran desarrollo en época posterior, como se comprueba en las construcciones basilicales representadas en los pavimentos bizantinos de Khirbat al-Samra, Khirbat al-Mukhayyat, Quweismeh, iglesia de San Esteban en Umm al-Rasas y Ma'in (figuras 25-26) ${ }^{48}$. Las representaciones de edificios aislados, a veces rodeados de muralla, constituyen la prueba de que un solo monumento, quizás el santuario principal de la ciudad, bastaba para ilustrar el topónimo, como ocurre en los mosaicos de Gerasa ${ }^{49}$, en donde las ciudades representadas corresponden, según Ehrensperger-Katz, más a

\footnotetext{
N. Duvat, Le rappresentazioni architettoniche, en M. PicciRili o-E. Alliata.. Umm Al-Rasas. Mayfa'ah. l. Gli scavi del compiesso di Santo Stefano. Jerusalem 1994, págs. 165-230.

J.W. CROWFOOT, Churches at Jerash, British School of Archaeology in Jerusalem, Suppl. 3 , London 1931, págs. 35 ss., especialmente pág. 41; C.H. KRAf LING. Gerasa. City of the Decapolis. New Haven 1938, págs. 342-349.
} 


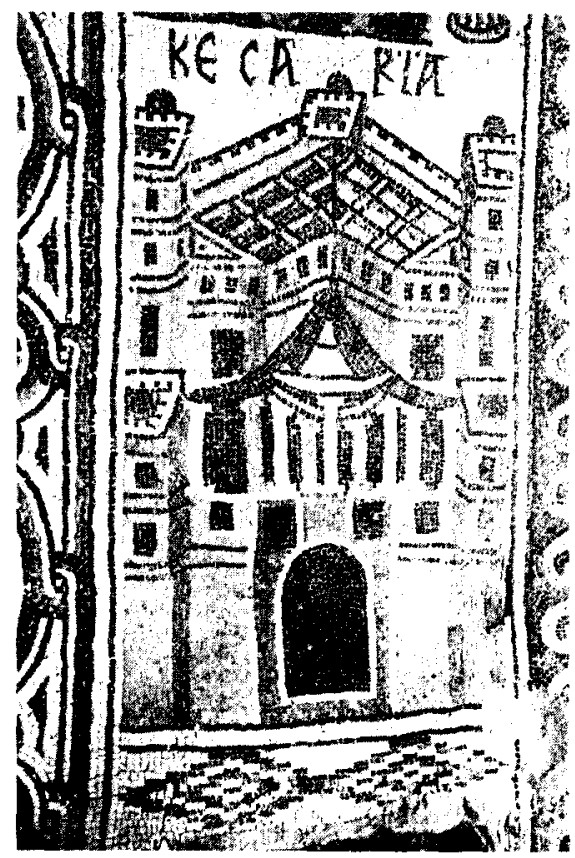

Figura 25. Mosaico de Umm al-Rasas, iglesia de San Esteban. Cesarea. Foto G. López Monteagudo.

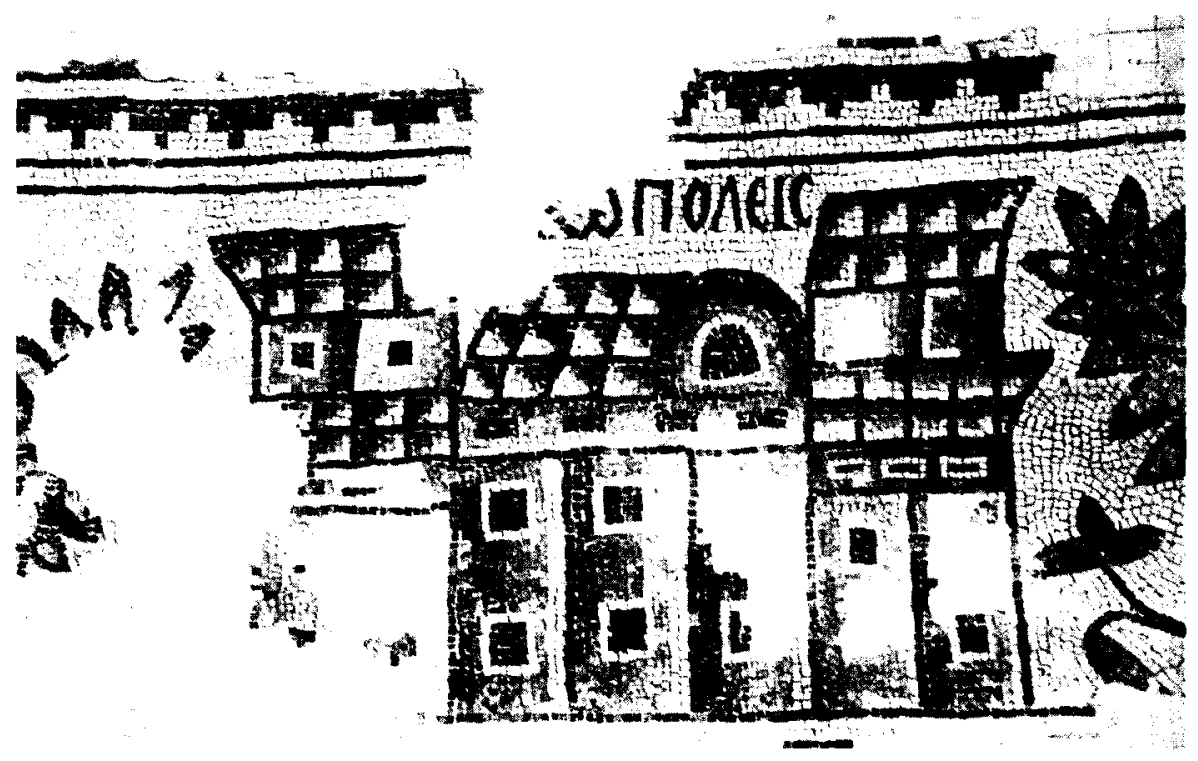

Figura 26. Mosaico de Main. Areópolis. Foto G. Lopez Monteagudo. 
un tipo iconográfico "prefabricado" que a la inspiración directa de la realidad, siguiendo la moda del Bajo Imperio que continúa en la Alta Edad Media, en la que bastaban unos pocos trazos realistas para que el modelo real fuera reconocido ${ }^{50}$. De esta forma, para hacer de la fórmula esquemática la imagen de una ciudad histórica determinada, bastaba con añadir la inscripción con su nombre y precisar algunos de sus edificios más carácterísticos, que en casi todos los casos era el santuario o el edificio basilical, habiendo desaparecido incluso el recinto amurallado en las representaciones de Quweismeh, Ma'in y en la iglesia del obispo Sergio en Umm al-Rasas, por considerarse que su presencia no era necesaria para asociar la imagen con la idea de la ciudad citada en el topónimo ${ }^{51}$. Se trata de imágenes convencionales, cuyos precedentes se hallan en las pinturas paleocristianas que, de esta forma, se convierten en el preludio de las "viñetas" de los mapas musivos y de los pictogramas de las tabulae pictae ${ }^{52}$.

Junto a estas construcciones de carácter sintético, ya sean ciudades o edificios determinados como las iglesias, hay en el mosaico de Madaba una predilección por representar las ciudades vistas en su conjunto, combinándose las panorámicas "normales» y las llamadas «a vista de pájaro». Y para ello se utilizan dos modelos arquitectónicos, uno de origen helenístico del que hay ejemplos también en Gerasa y en la mezquita de Damasco, que remonta a la pintura ilusionista de Demetrios de Alejandria, pintor del siglo ॥ a.C. Ilamado el "topógrafo", que consiste en mostrar las ciudades en perspectiva aérea oblicua, fórmula que pasa posteriormente al arte romano y paleocristiano junto a la influencia naturalista del Neoaticismo. La característica más sobresaliente de este tipo de representaciones, que en la Carta de Madaba (figuras 27-29) ilustran los topónimos de Ashdod, Athribis, Azotos Paralos, Belen, Bersabea, Beth Zachar, Charach Moba, Diospolis, Eleutheropolis, Gaza, Hagiapolis, Iamnia, Nicias. Nikopolis, Pilousin, es la forma de concebir el fondo como una superficie plana, de la que "salen» los edificios colocados tridimensionalmente contra ella.

\footnotetext{
5. I. Ehrensperger-Katz, Les répresentations de villes fortifiées dans l'art paléochrétien et leurs dérivées byzantines, Cahiers Archéologiques XIX, 1969, págs. 1-27.

P.A. FEvRIER, Images de la ville dans la Chrétienité naissante, Actes du Xle Congrès International d'Archéologie Chrétienne, Roma 1989, II, págs. 1371 ss, en especial 1385-92, opina que lo esencial de la topografía reside en la evocación de los lugares de culto; G. LOPEZ MONTEAGUDO, Modelos clásicos para las pinturas de San Isidoro de León, VI Jornadas de Arte "La visión del mundo clásico en el arte espariol", Madrid 1993, págs. 25-35.

52. F. BISCONTI, Le rappresentazioni urbane nella pittura cimetariale romana: dalla città reale quella ideale, Actes du Xle Congrès International d'Archéologie Chrétienne, Roma 1989, II, págs. 1305 ss., especialmente pág. 1311.
} 


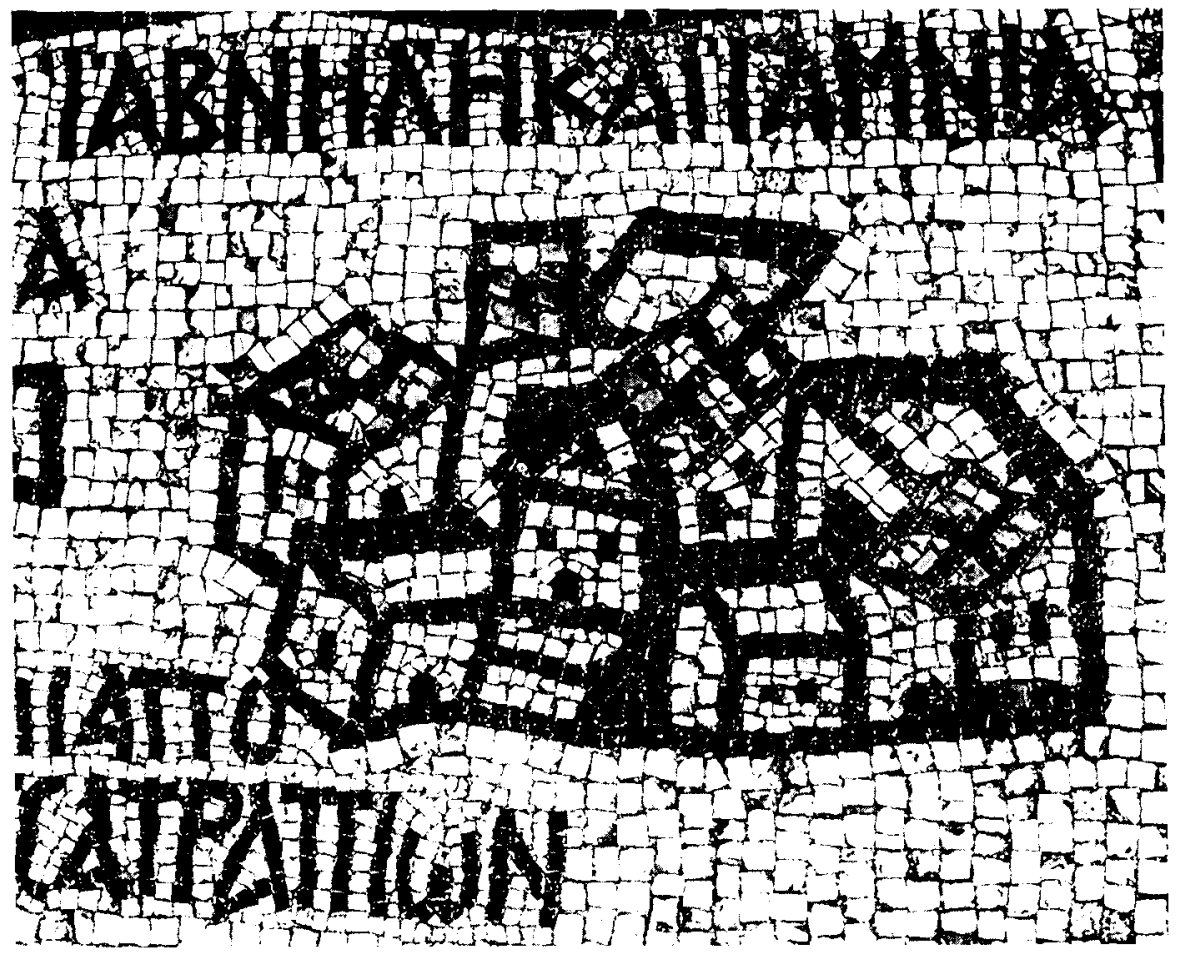

Figura 27. Mosaico de Madaba. lamnia.

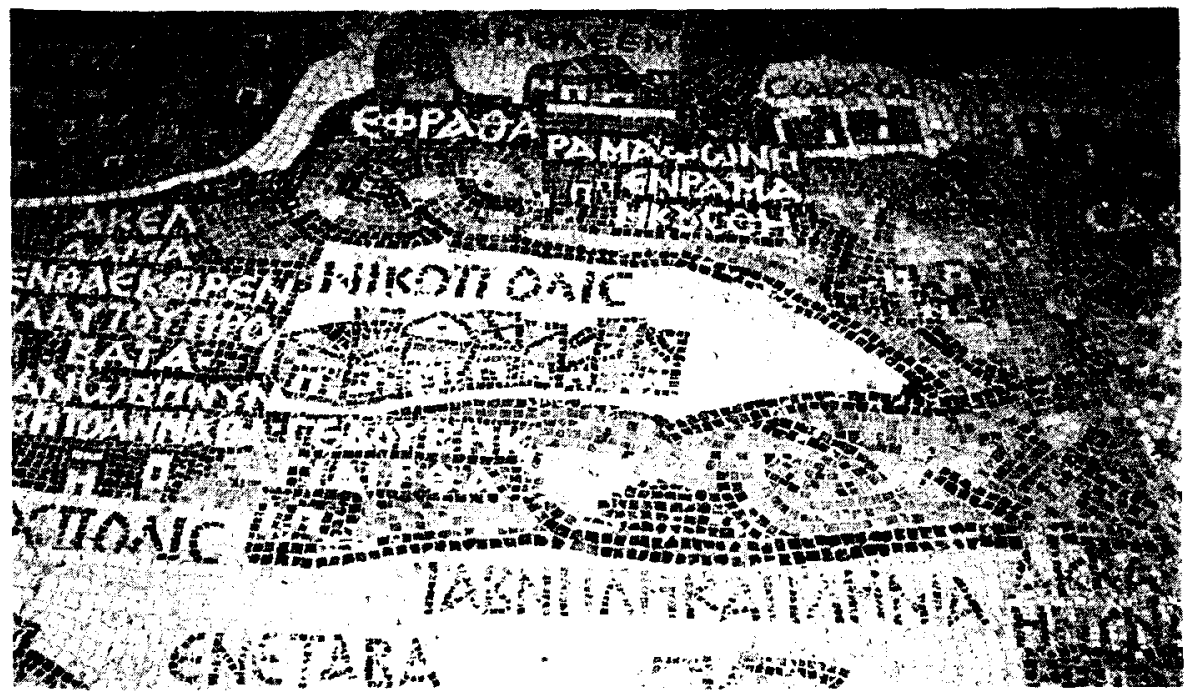

Figura 28. Mosaico de Madaba, Nikópolis. Foto G. López Monteagudo. 


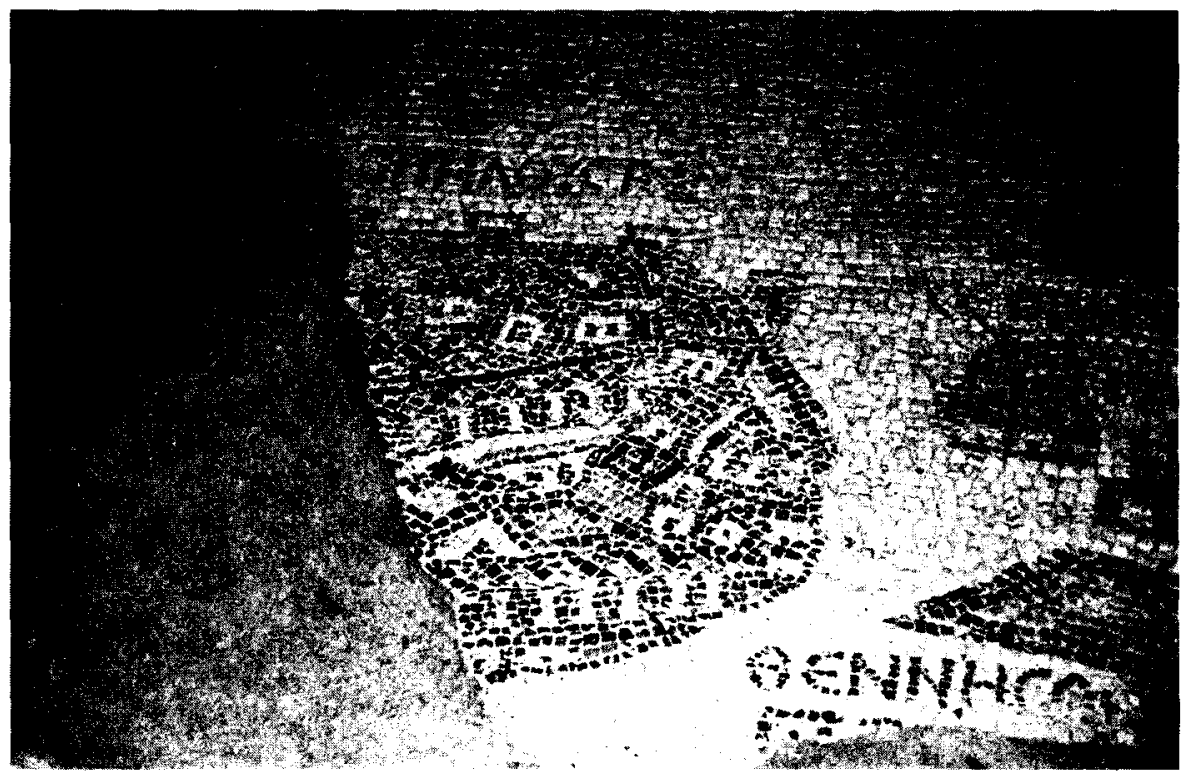

Figura 29. Mosaico de Madaba. Pilousin. Foto G. López Monteagudo.

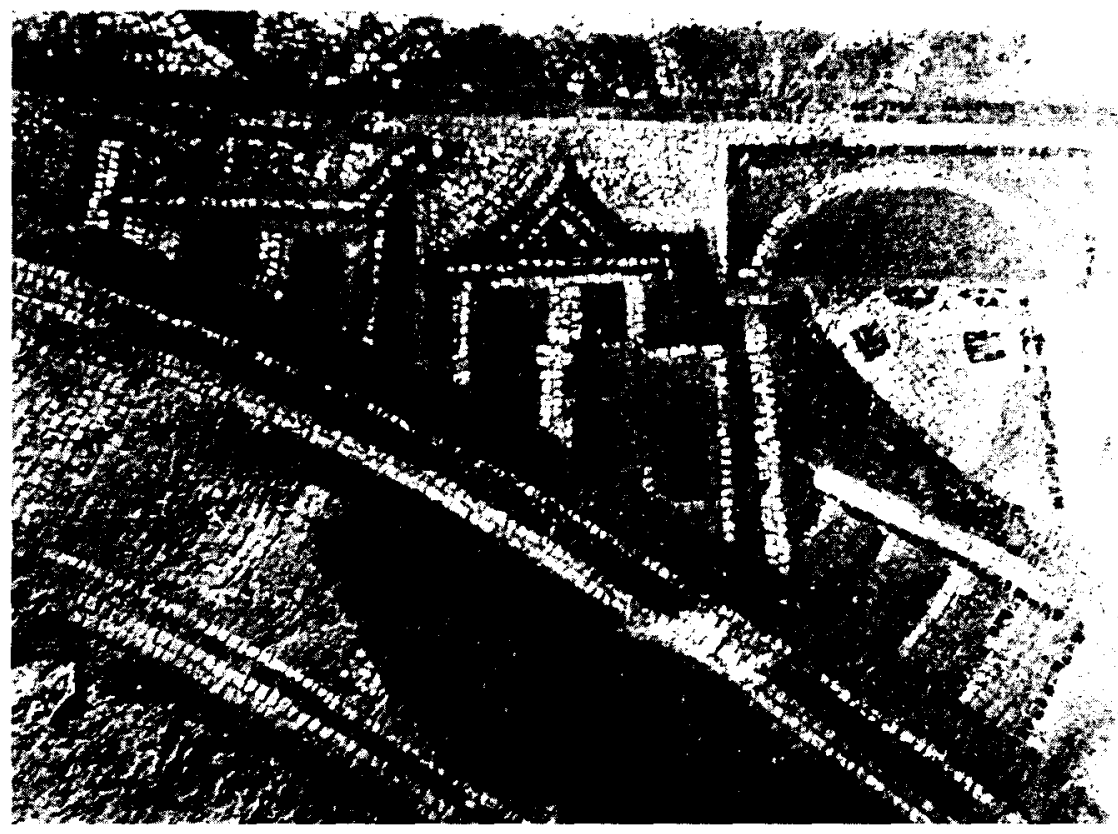

Figura 30. Mosaico de Puigvert de Agramunt. 
En la musivaria hispana un ejemplo de este tipo de representaciones lo constituye el mosaico hallado en la villa romana de El Reguer (Puigvert de Agramunt, Lérida), que se fecha en el último cuarto del siglo Iv (figura 30), del que se conservan solamente dos fragmentos ${ }^{53}$. En uno se ha representado un venator enfrentándose a un león, dentro de un espacio de forma elipsoidal que figura el anfiteatro; el otro muestra una serie de edificios en el espacio triangular resultante de la inserción del círculo en un cuadrado, en torno a esa línea, es decir, ya fuera de la arena. Comenzando por la derecha se ve, en primer término, una especie de escalera o de pórtico y una gran arcada sobre columnas, con cortina recogida a un lado; sigue un edificio cuadrangular de dos pisos, con puerta rectangular en el primero y dos ventanas cuadradas en el segundo, una especie de columna en el centro de la fachada y tejado a dos aguas; a continuación otro edificio cuadrangular, del que solo se ve la parte superior con dos ventanas cuadradas y cubierta plana; y junto a él una construcción circular. Vista en su conjunto, la representación urbana del mosaico hispano-romano recuerda muy de cerca a las edificaciones que conforman las ciudades de Nikopolis, lamnia o Hagiapolis, y sobre todo de Gaza en el mosaico de la Carta de Madaba. Por su parte, los detalles arquitectónicos y ornamentales de los edificios determinados, como las ventanas cuatripartitas y las cortinas recogidas a un lado en ventanas o puertas, que también se documentan en mosaicos norteafricanos de los siglos III al $\mathrm{V}$, se repiten en numerosos pavimentos paleocristianos y bizantinos, con preduración en los siglos posteriores ${ }^{54}$.

El mosaico hispano de tipo alejandrino, procedente de La Vega Baja de Toledo, participa de las mismas características apuntadas anteriormente en las representaciones de ciudades en la "Carta» de Madaba. Las escenas portuarias en él representadas están realizadas desde una perspectiva plurifocal, sin aparente conexión entre unas y otras; solo la temática a base de barcos, pescadores y edificios al borde del mar con un fondo de árboles, proporciona unidad al cuadro ${ }^{55}$. Esta ambigüedad en la forma de

CMRE IX, 1989, págs. 21-23, n²1, lám. 9; G. LOPEZ MONTEAGilluo, Escenas de venatio en mosaicos hispano-romanos, Gerión 9, 1991, págs. 255-258.

54 G. Lopez MONTEAGudo, Representaciones de ciudades en mosaicos romanos del Norte de África, L'Africa Romana X (Oristano 1992) Sassari 1994, págs. 1.242-1.257; 1D., The Maps in the Byzantine Period. Origin and Transfer of the architectonic Models on the Mosaic and Picture from Spain, International Colloquium "The Madaba Map Centenary 1897-1997: Travelling through the Byzantine-Umayyad Period (Amman-Jordania, 1997), en prensa.

b5 CMRE V, 1982, págs. 33-36, ñ25, láms. 16-19 y 46; A. BaLli, Monumentos alejandrinos y paisajes egipcios en un mosaico romano de Toledo (España), Studi in onore di Achille Adriani 3. Roma 1984, págs. 433-439: G. Lopez MoniteaGiudo, Representaciones de ciudades en mosaicos romanos del Norte de África, L'Africa Romana X (Oristano 1992) Sassari 1994, págs. 1.242 1.257, Tav. IX. 
utilizar las distintas perspectivas se repite en otros mosaicos topográficos de Jordania de los siglos VI al VIII, como los de Khirbat al-Samra, Gerasa o Umm al-Rasas.

La otra forma de representar las ciudades en el mapa de Madaba es la llamada "a vista de pájaro", que produce una perspectiva plana (Hagiapolis, Neapolis, Askalon, Gaza y Pilousin). El modelo se encuentra también en la antigüedad clásica y se utiliza de forma especial en la representación de peristilos y jardines en los mosaicos de Pupput y Thuburbo Maius (Túnez), Carranque y La Vega Baja de Toledo (España), Burdeos, Loupian y Saint-Rémy-la-Varenne (Francia) ${ }^{56}$. El peristilo semicircular porticado que en la "carta" de Madaba se localiza en las ciudades de Diospolis y Gaza, y también en el lugar de San Zacarías (figuras 31-33), quizás obedeciendo a la forma de representar la columnata pseudoperíptera típica de los templos, muestra estrechos paralelismos con los peristilos semicirculares figurados en los mosaicos de La Vega Baja de Toledo (figura 34) ${ }^{57}$ y

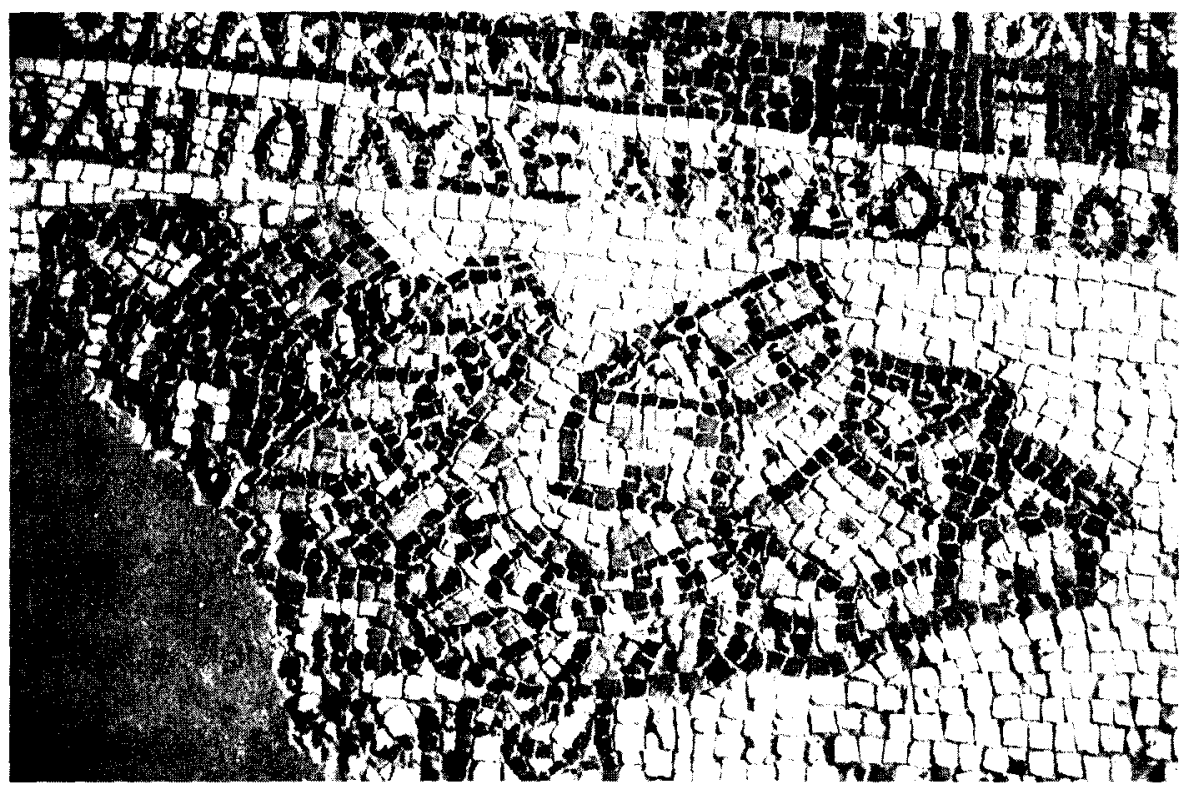

Figura 31. Mosaico de Madaba. Diospolis. Foto G. López Monteagudo.

Véase en este mismo volumen el trabajo de M.P. SAN NICOLAS PEDRAZ, Los espacios ajardinados en la musivaria romana, págs. 137-175.

CMRE V. 1982, láms. 20 y 47 . El peristilo representado en el mosaico de los peces de la villa romana de la Vega Baja de Toledo, formado por once columnas que se levantan sobre un basamento escalonado, se halla constatado arqueológicamente en la villa romana de Rielves. 


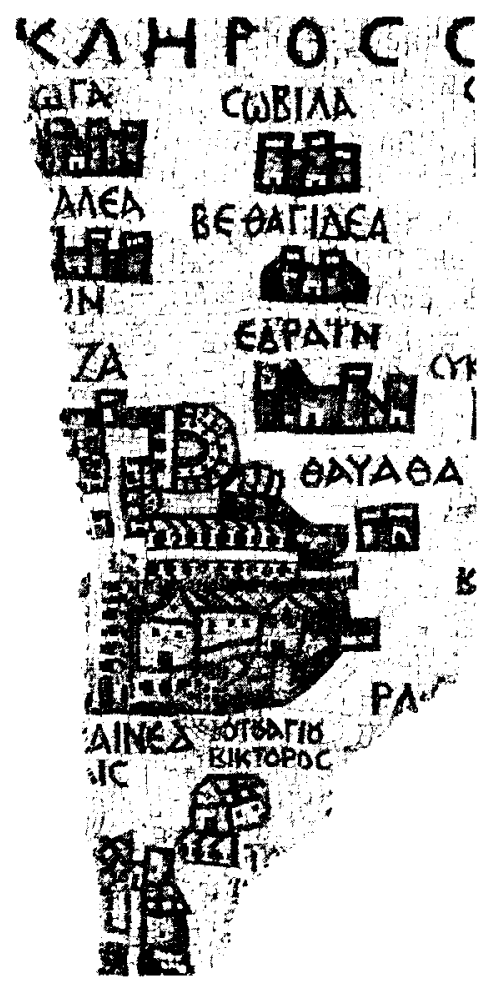

Figura 32. Mosaico de Madaba. Gaza y San Victor.

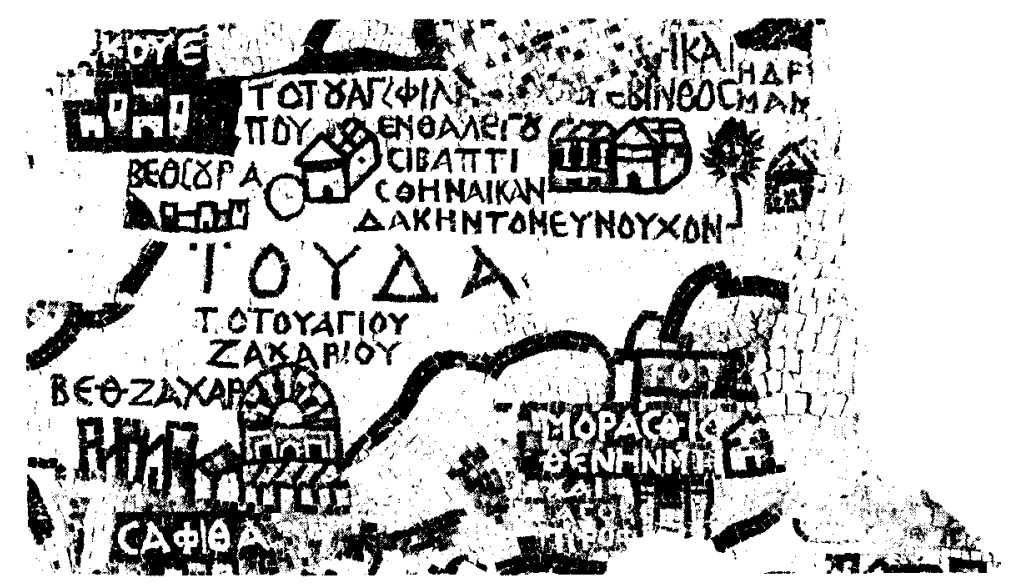

Figura 33. Mosaico de Madaba. Bethsura, Beth Zachar, Ekoue, San Felipe, San Zacarias y Terebinto. Foto G. López Monteagudo. 


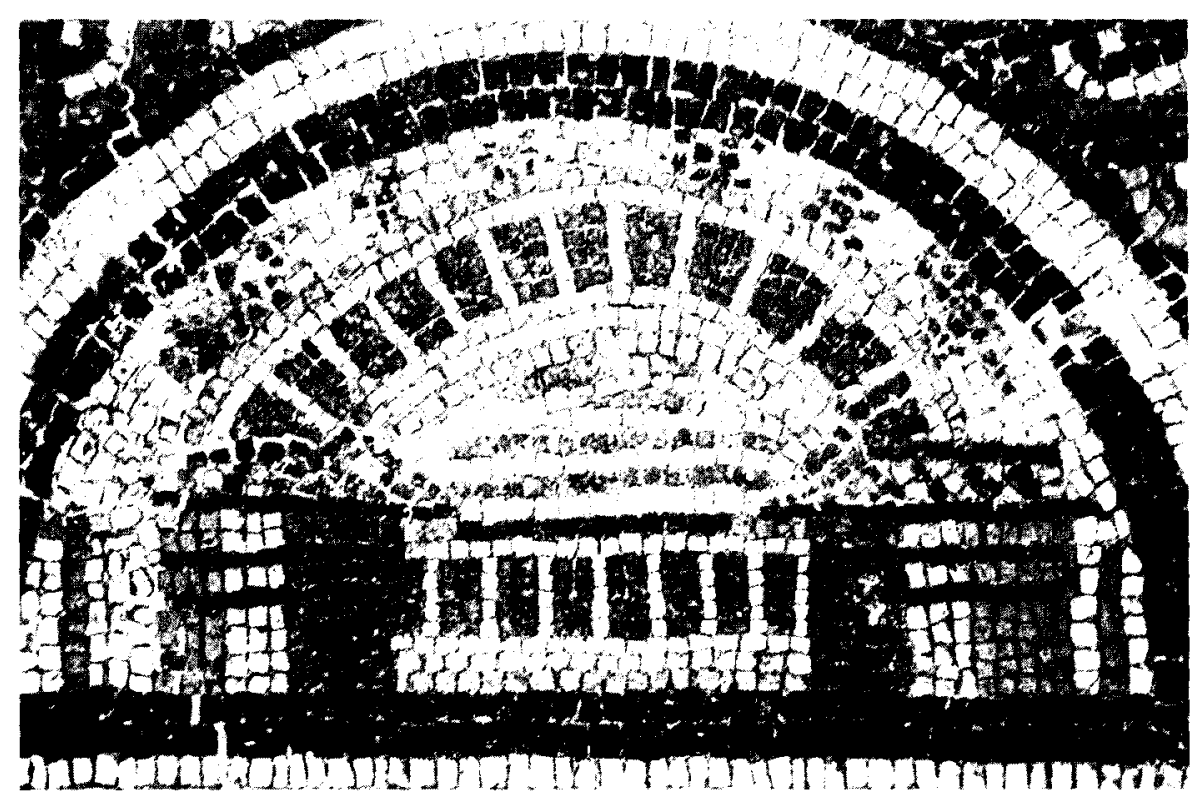

Figura 34. Mosaico de La Vega Baja de Toledo. Villa de peristilo

de Henchir Toungar ${ }^{58}$, o en la sítula de Roma ${ }^{59}$, documentos datados en los siglos III-IV. El éxito alcanzado por el modelo arquitectónico hizo que se transmitiera de Occidente hasta el Oriente, en donde se documenta no solo en el pavimento de Madaba, que se fecha en el siglo vi d.C., sino que incluso se perpetúa en los mosaicos de la mezquita de Damasco, con una cronología ya en el vill d.C. (figura 35).

El punto culminante de la "carta" de Madaba lo constituye la representación de la ciudad santa de Jerusalén (figura 36), centro ideal de la composición a pesar de no ocupar el centro físico de la misma. La ciudad está representada de forma realista, con sus murallas y puertas, con sus calles y edificios principales, que han sido identificados por distintos investigadores con la ayuda de las fuentes antiguas, combinándose en todos ellos las distintas perspectivas que se hallan documentadas en la Carta de Madaba: aplanada, áerea oblícua y a vista de pájaro. De la puerta Norte, antigua puerta de

lechada en la primera mitad del siglo N, localizada también en la provincia de Toledo. cf. M.C. Fehnandtz Castho, Villas romanas de España. Madrid 1982, págs. 111-112, figs. 53-54

K.M.D. Dunzabin. The Mosaics of Roman North Africa, Oxford 1978, pág. 262, pl. 23.

A. Carandini, La situla tardo-antica dell Antiquarium Comunale, Buli Comm. Arch. di Roma LXXIX, 1966, págs. 148-162. 


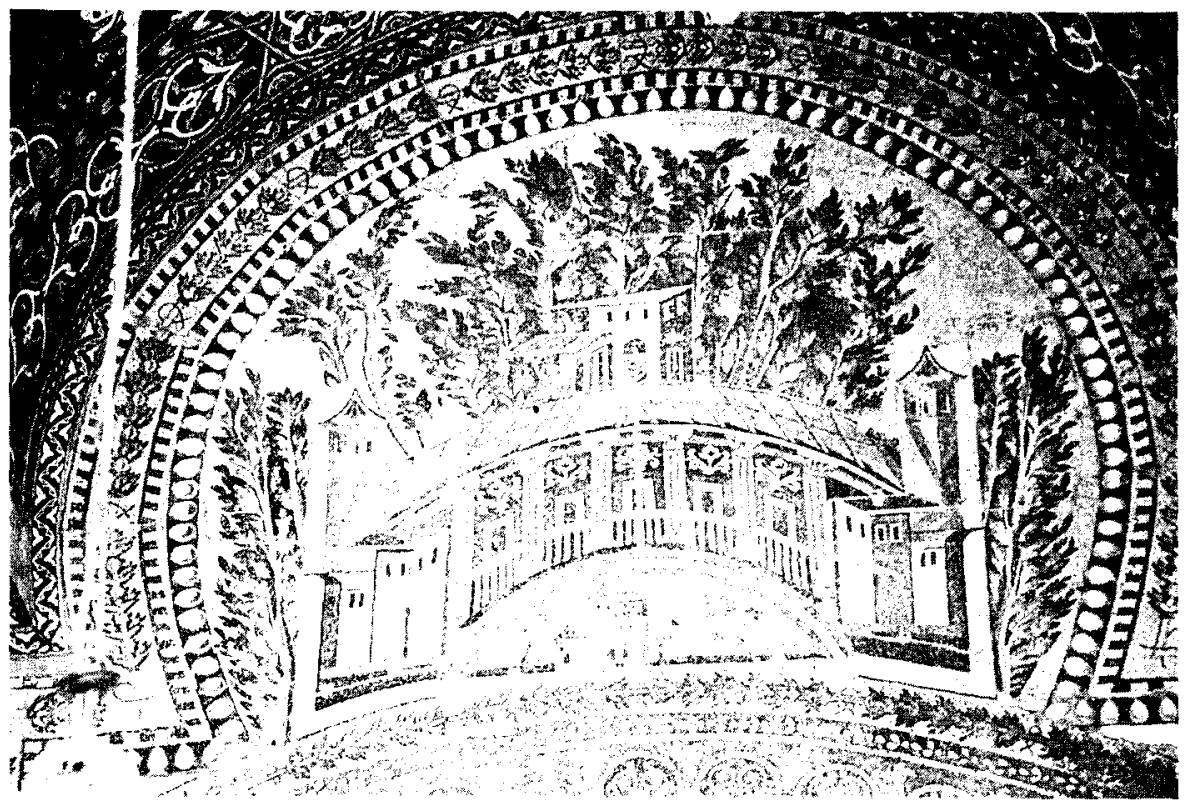

Figura 35. Mosaico de la Gran Mezquita de Damasco. Foto G. López Monteagudo.

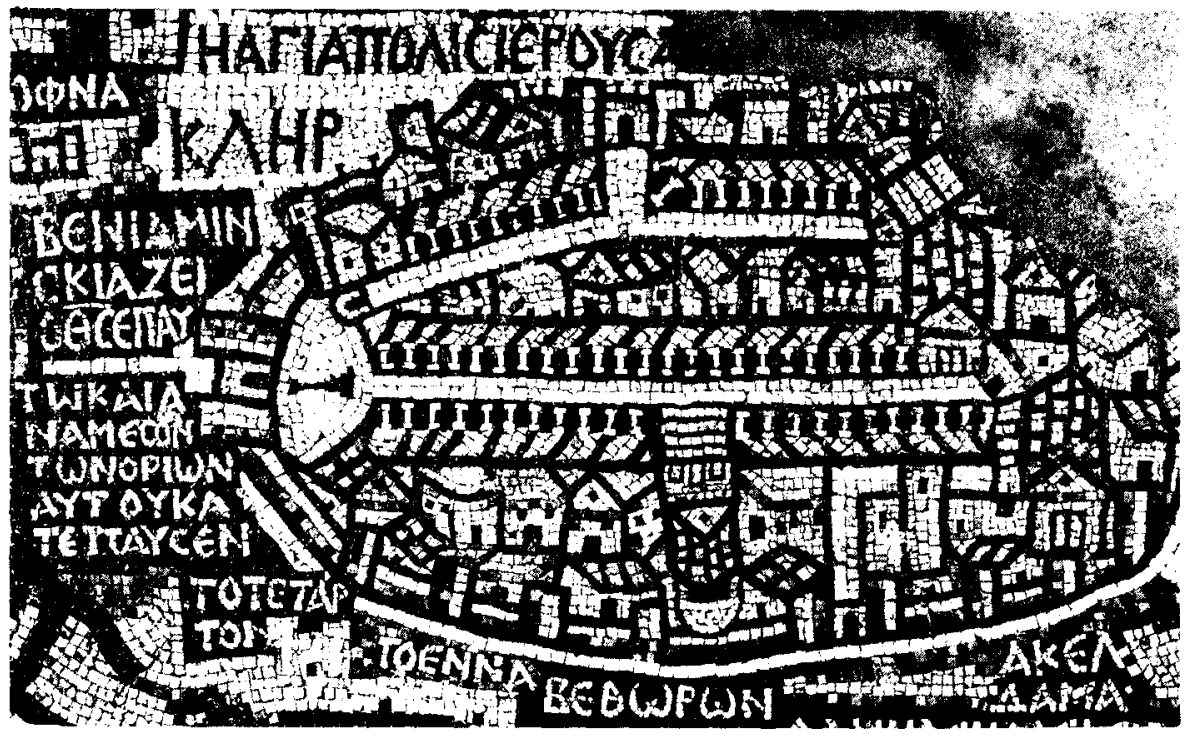

Figura 36. Mosaico de Madaba. Jerusalen. 
San Esteban o de la Columna, llamada asi por la columna honorífica que se levantaba en el centro de la plaza de la ciudad hadrianea Aelia Capitolina, parten el cardo maximus, conservado bajo el nivel de la ciudad actual, dominado por el complejo constantiniano del Santo Sepulcro, y una calle secundaria que se dirige hacia el valie del Tyropeion y que, a la mitad del recorrido, se cruza con la actual vía Dolorosa, que viene de la puerta oriental llamada actualmente de San Esteban o de los Leones, en cuyo interior se ha identificado el conjunto formado por la piscina Probática o de Bethesda, la basílica bizantina y el complejo termal de época romana dedicado a Esculapio, ruinas que pueden contemplarse junto a la iglesia de Sta. María o Sta. Ana, a la derecha de la vía Dolorosa, ascendiendo desde la puerta Este. En la Puerta de David, al Oeste, comienza el decumanus, alineado con la actual calle de David. En el extremo Sur del cardo maximus se distinguen dos grandes basílicas, identificadas con Santa Sión y con la Nea Theotocos justinianea, que ha sido localizada recientemente en el barrio occidental de Jerusalén.

Entre los edificios que forman parte de algunos de los diferentes tipos de ciudades representadas en el mosaico de Madaba (Agbaron. Azotos Paralos, Betabara, Betagla, Charach Moba, Diospolis, Gaza, Hagiapolis, Pilousin, Terebinto), asi como en las iglesias de San Felipe, San Lot y San Victor y el lugar del pozo de Jacob (figuras 8 y 37), destaca un tipo de construcción rectangular, visto en perspectiva angular, a veces

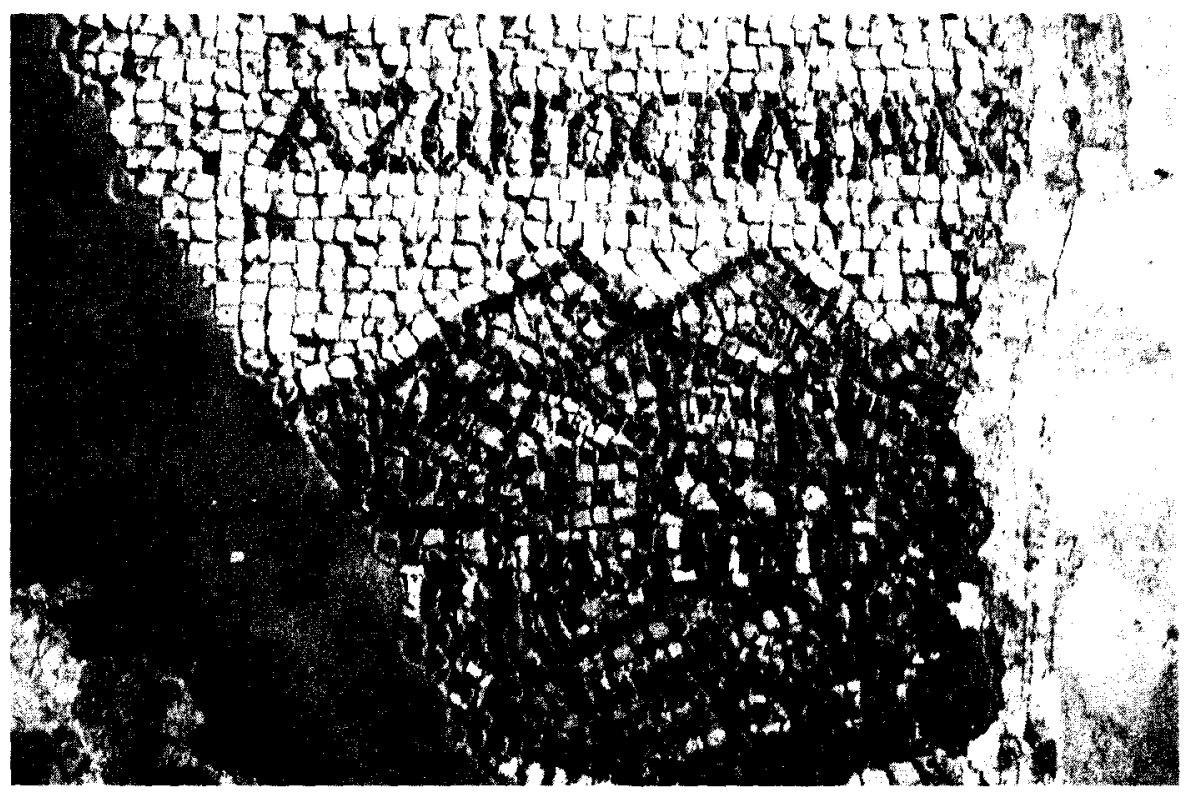

Figura 37. Mosaico de Madaba. Azotos Paralós. Foto G. López Monteagudo. 


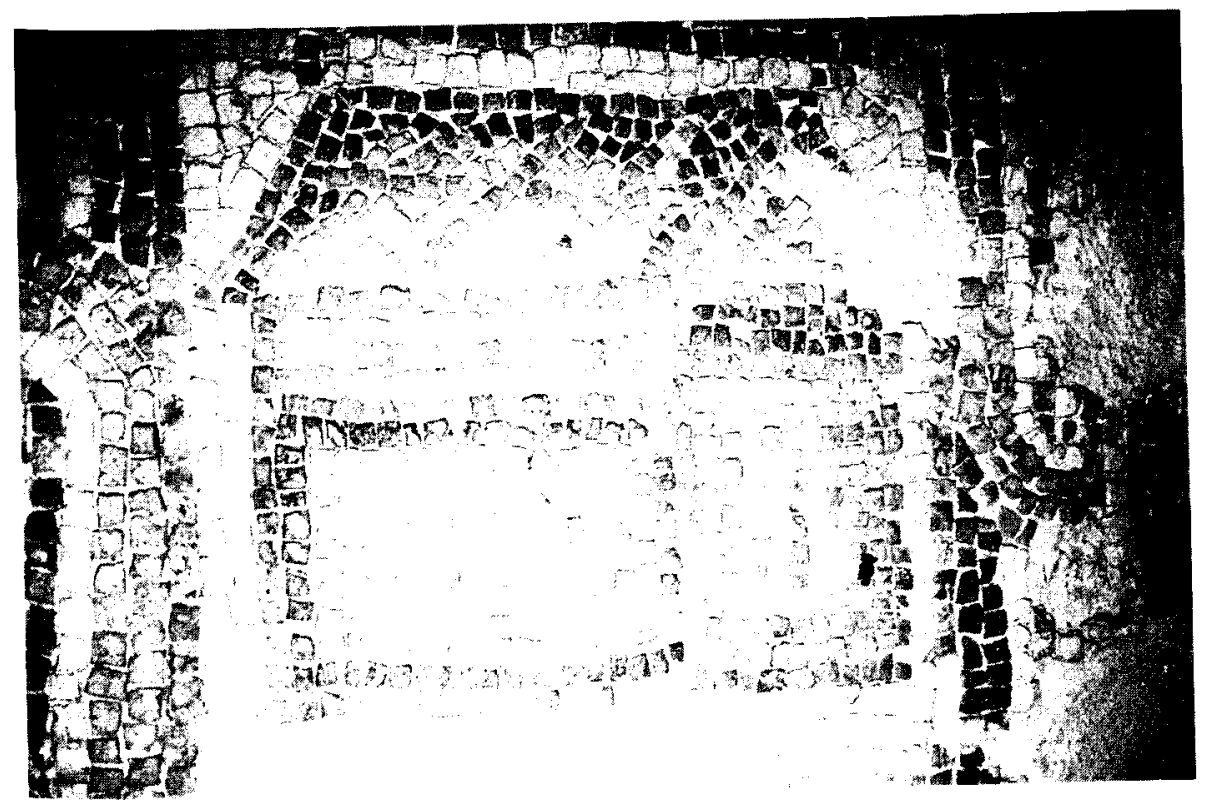

Figura 38. Mosaico de Quweismeh. Foto G. López Monteagudo.

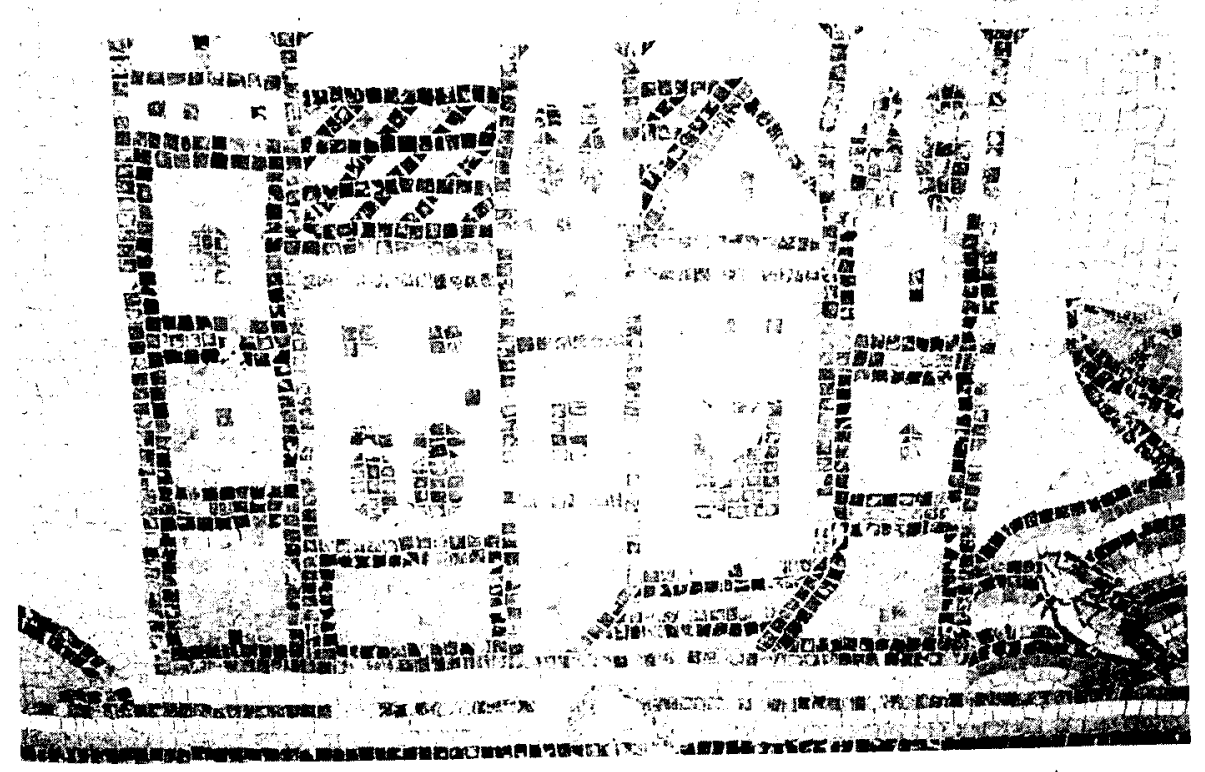

Figura 39. Mosaico de Khirbat al-Mukhayyat. Foto G. López Monteagudo. 


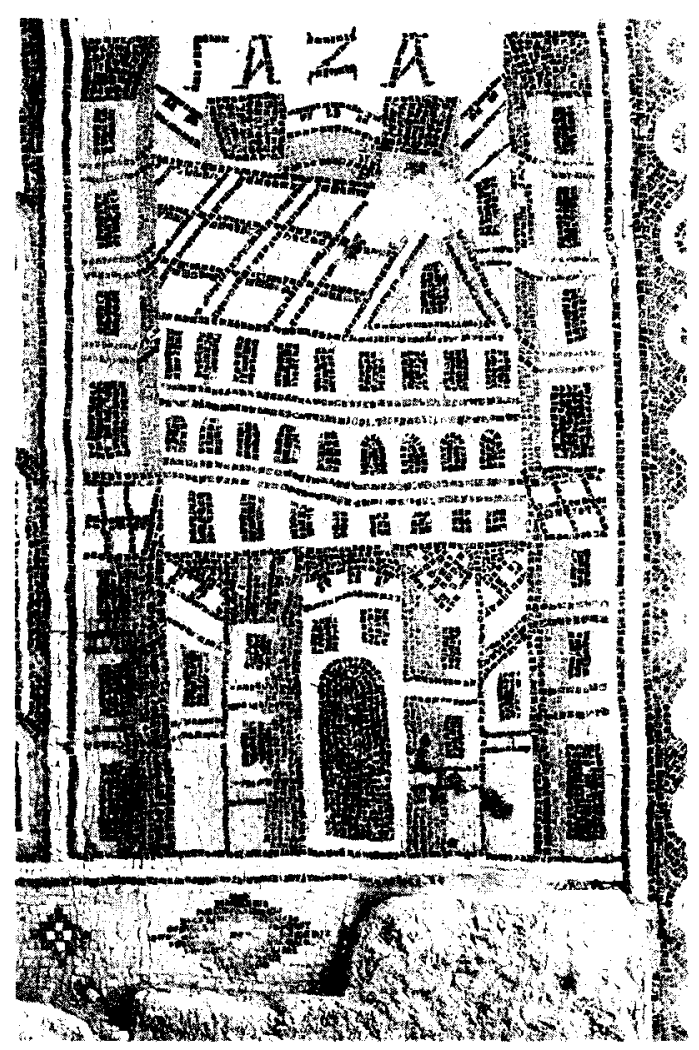

Figura 40. Mosaico de Umm al-Rasas. iglesia de San Esteban. Gaza. Foto G. López Monteagudo.

con las dos fachadas en un mismo plano, que también se documenta en la Tabula Peutingeriana, en mosaicos sirios de la misma fecha, con representación de iglesias ${ }^{60}$, o en los pavimentos jordanos (figuras 3840) de Quweismeh, Gerasa, Khirbat al-Mukhayyat, Ma'in y de Umm alRasas, en donde destaca la gran profusión de ventanas abiertas en los edificios y la presencia de cortinajes recogidos en algunos de ellos ${ }^{6}$, y pervive en la decoración musivaria de la mezquita de Damasco (figura 41), continuando la tradición iconográfica del siglo $\mathrm{IV}$ d.C. dentro del ideal del gusto helenístico. El modelo arquitectónico, provisto de frontón y a

N. Duval, Représentations d'églises sur mosaïques, Revue du Louvre et des Musées de France XXII, 1972, págs 441-448.

M. Piccinillo, Madaba. Le chiese e i mosaici, Milano 1989, págs. 186, 233, 278, 288-289. 294-300; ID., The Mosaics of Jordan. Amman 1993, págs. 196-201, 219-235, 258, 273. 


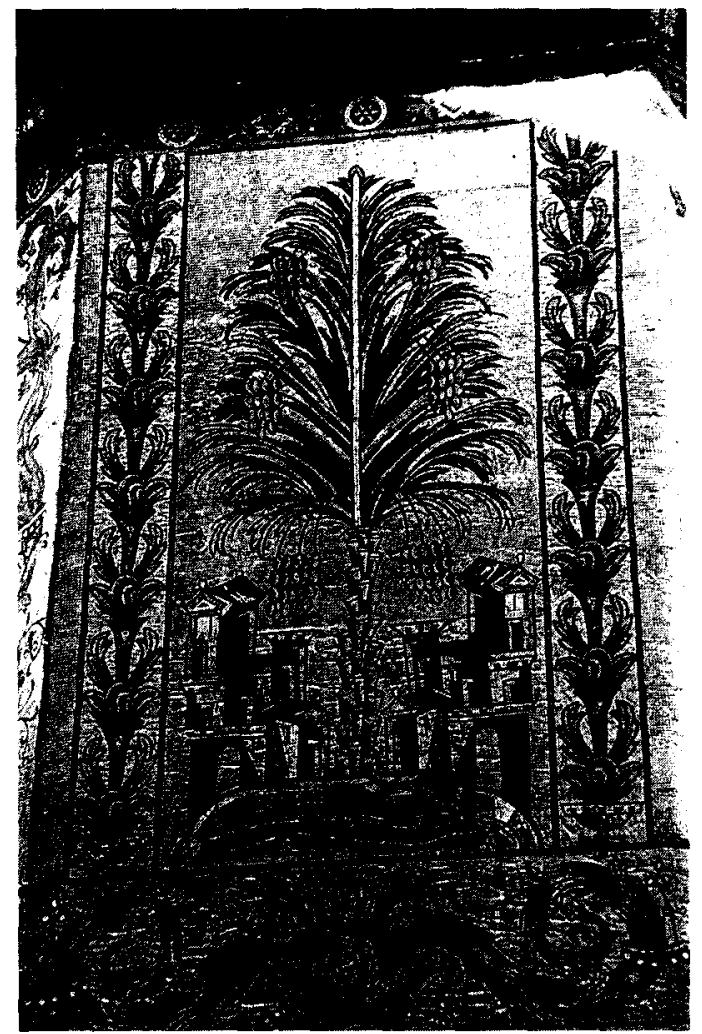

Figura 41. Mosaico de la Gran Mezquita de Damasco. Foto G. López Monteagudo.

veces de una escalinata, se encuentra ya a mediados del siglo I d.C. en las pinturas de la tumba de los Nasonii ${ }^{62}$, así como en las representaciones de los templos romanos y aparece en numerosos documentos con distintos significados: templo pagano en los manuscritos de la Antigüedad Tardía (Vergilius Vaticanus, llias Ambrosiana); casa o habitación (mosaicos de Sta. María la Mayor de Roma); y tumba de Lázaro (pinturas y sarcófagos paleocristianos). Según E. Billig, el tipo arquitectónico es independiente de la utilización del edificio, a pesar de algunas diferencias en los detalles, como la columnata pseudoperiptera que se emplea en el templo, las cortinas y lámparas en la casa, o la escalera de acceso y alto podio en la tumba. Es decir, se trataría de un tipo estereotipado, independiente de su utilización, que caracteriza el periodo de la

S. REINACH, RPGR, pág. 13, 4 
antigüedad tardía y que se constata por ejemplo en las «viñetas» del Psautier de Utrech ${ }^{63}$.

El tipo de construcción en perspectiva angular, con frontón, cubierta a dos aguas y ventanas alineadas en la fachada, que se utiliza frecuentemente, como hemos visto, en el pavimento de la Carta de Madaba para figurar tanto las arquitecturas de carácter religioso, como los edificios integrados en las ciudades, se atestigua frecuentemente en la musivaria romana, baste citar el pavimento de Utica con escena de caza, de comienzos del siglo $1{ }^{64}{ }^{64}$, uno de los paneles del pavimento de Orfeo de Leptis Magna, datado en el mismo siglo ${ }^{65}$, los mosaicos de Cartago con escenas marinas, de comienzos del siglo IV, y de Cartago-Khéreddine, que se fecha a fines del iv o comienzos del $v^{66}$, las representaciones contemporáneas de villae rústicas de Tabarka, o el compartimento decorado con escenas pastoriles del mosaico constantiniano de las Estaciones de Daphne, que se conserva en el Louvre (figura 42) ${ }^{67}$. En Hispania, el
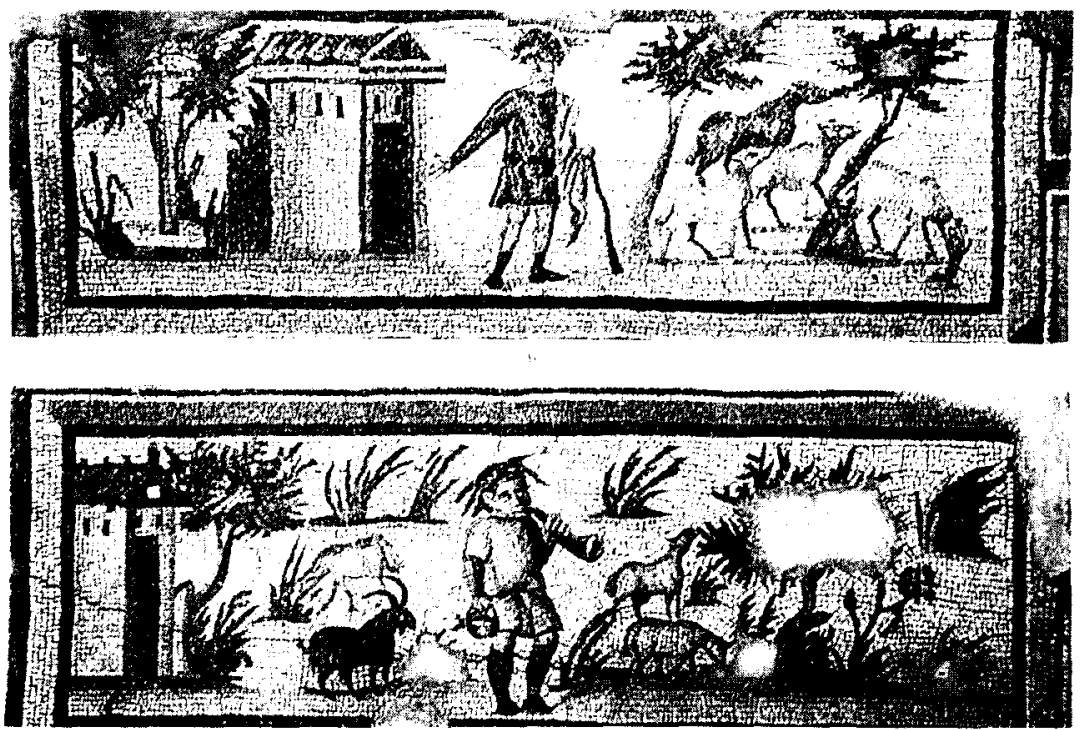

Figura 42. Mosaico de Daphne.

E. But ki. Spätantike Architekturdarstelfungen I. Stockholm 1977, págs. 47-80: N. Duval. La représentation des monuments dans l'Antiquité Tardive. A propos de deux livres récents. Bulletin Monumental 138/1, 1980, págs. 88-95.

CMT 1/3, Tunis 1976. págs. 22-25. pl. XIV y XLI.

S. Auszicimma. L'talia in Africa. Tripolitanial I mosaici, Roma 1960, Tav. 112.

K.M.D. Dunbabin. The Mosaics of Roman North Africa, Oxtord 1978, pl. 35, 112-3, 126-127.

D. Lr vi. Antioch Mosaic Pavements. Princeton 1947. pl. LIX. 
mismo modelo arquitectónico aparece representado en las pinturas que decoran la bóveda del mausoleo de Centcelles ${ }^{68}$ y en uno de los semicírculos del mosaico de los peces, procedente de la villa romana de La Vega Baja de Toledo, en el que se han figurado dos edificios cuadrangulares, con frontón, tejado a doble vertiente y puertas en forma de $T$ en la fachada principal, particularidad esta última que se repite en los mosaicos toledanos y que también se documenta en el citado pavimento de Orfeo de Leptis Magna ${ }^{69}$. El edificio con escalera de acceso y alto podio, que forma parte de la ciudad de Azotos Paralos en la carta de Madaba (figura 37), se documenta en algunas representaciones musivarias de villas marítimas de época romana, baste citar el mosaico de Océanos de Bad Kreuznach (figura 43), de mediados del siglo $1{ }^{70}{ }^{70}$, los paneles vidriados de Kencherai (figura 19), que se fechan hacia 350 d.C., en donde el mismo tipo de construcción aparece documentado varias veces "', y el

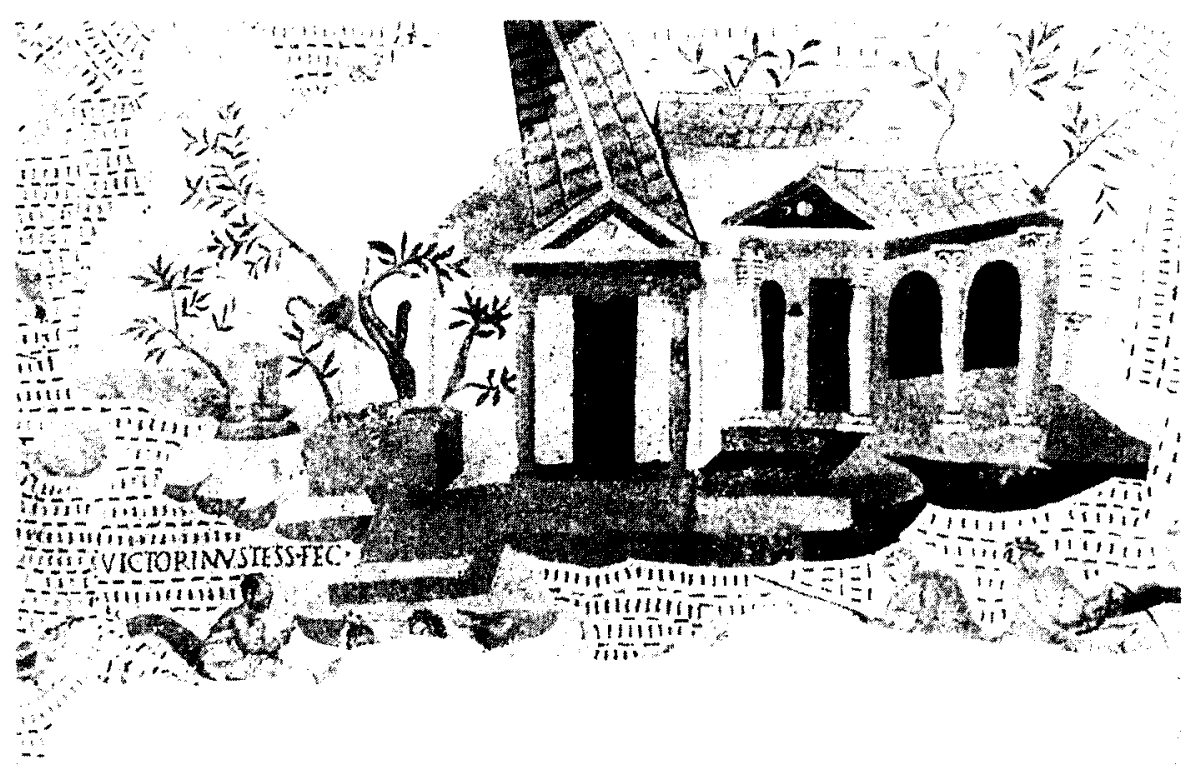

Figura 43. Mosaico de Bad Kreuznach. Foto G. López Monteagudo.

H. Sorilunk. Th. Hauscril os, Intorme preliminar sobre los trabajos realizados en Centcelles. Excavaciones Arqueológicas de España 18. Madrid 1962, lám. XXIV; H. SCHLUNK. Die Mosaikkuppel von Centcelles, Mainz 1988, págs. 97-98, Taff. 24c y 35b.

CMRE V, 1982, págs. 36-40, $n^{\circ} 26$, láms. 22 y 48

G. Rupprecht. Römische Steinteppiche. Die Mosaïkböden der Peristylvilla in Bad Kreuz. nach, ArchDeutschland 3, 1989, págs. 18-21.

L. IBrahim et alii. Kencheral, II, Leiden 1976. 
mosaico con escena fluvial de Santa Maria in Trastévere de Roma ${ }^{72}$. En el pavimento del peristilo de la villa hispano-romana de la Vega Baja de Toledo, de fines del siglo III o comienzos del IV, en el que se han figurado escenas portuarias de tipo alejandrino, aparecen dos edificios de estas características, de forma cuadrangular, con acceso escalonado, ventanas en los pisos superiores y tejado a dos aguas, junto a una construcción circular con tejado cónico ${ }^{73}$. En un mosaico procedente del llamado triclinio de Apamea de Siria (figura 44), fechado en el segundo cuarto del s. IV, se representa también un paisaje portuario de estilo alejandrino, con edificios escalonados provistos de embarcadero y un faro que tal vez pudiera hacer referencia al de Alejandría ${ }^{74}$.

En síntesis, puede decirse que en la Carta de Madaba las ciudades, tanto de carácter simbólico como realista, están vistas de forma sintética, característica típicamente romana en donde la perspectiva es frecuentemente una ilógica e incoherente combinación de panorámicas "normales" y «a vista de pájaro" sobre una superficie plana ${ }^{75}$, descrita por Kitzinger como "un fondo neutro de profundidad indefinida" ${ }^{76}$. El modelo pudo

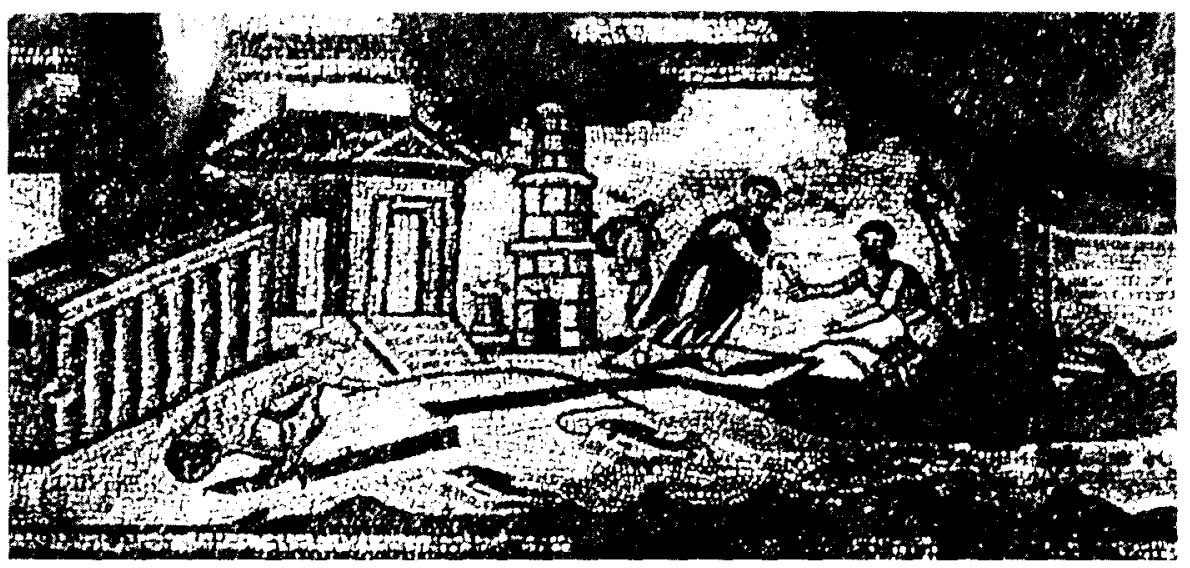

Figura 44. Mosaico de Apamea.

M. Rosiovin11. Die hellenistisch-römische Architekturiandsschaft. RM. XXVI, 1911, fig. 64 CMRE V. 1982, págs. 33-36, n־25, láms. 16-18 y 46: A. Bal.I. Monumentos alejandrinos y paisajes egipcios en un mosaico romano de Toledo (España), Studi in onore di Achille Adriani 3. Roma 1984. págs. 433-439

J. BAI TY. Mosaïques antiques de Syrie, Bruxelles 1977. págs. 70-71; J. Ch. BAi Tr. Guide dApamee. Bruxelles 1981, págs. 98-99, figs. 101 y 103

P.H. BI ANCHI NIInGi N. Narration in Hellenistic and Roman Art, AJA 61. 1957, pags. 79-83.

E. Kil/incit.h. Stylistic Developments in pavement Mosaics in the Greek East from the Age of Constantine to the Age of Justinian, CMGR I, Paris 1965, pags. 341-352. 
haber sido un mapa romano adaptado a la geografía bíblica para uso de los peregrinos que visitaban los loca sancta ${ }^{77}$.

Según I. Ehrensperger-Katz, el carácter realista de las edificaciones de Madaba, que se encuentra también en otras representaciones de procedencia africano-oriental de la misma época, se explica mejor por la estética local de Palestina, que por la hipótesis según la cual el mosaico de Madaba seguiría una tradición propia a la cartografía. Así, las características de este tipo de representaciones, de las que Madaba no es el único ejemplo, las resume la autora diciendo que no se reproduce lo que el ojo ve, es decir, el reflejo o la impresión de la imagen que se percibe en la retina y que está en la base de la trasposición en imagen de un objeto real, sino que se niega la vista llamada natural para recomponer un objeto según los datos científicos, en busca no de la apariencia, sino de la verdadera realidad de los objetos, que se enumeran en el orden de su importancia ideal. Ello explica que las representaciones de este tipo se parezcan más a diseños geográficos que a obras de arte. $Y$ es también este proceso intelectual el que establece un lazo de parentesco entre los artistas cristianos anteriores al Renacimiento y el creador del mosaico de Madaba ${ }^{78}$.

Y. TSAF RIR, The Maps used by Teodosius: on the Pilgrim Maps of the Holy Land and Jerusalem in the sixth century C.E.. DOP 40, 1986, págs. 129 ss.

1. EtrRENSPERGith-Ka1L, Les répresentations de villes fortifiées dans l'art paleochrétien et leurs dérivees byzantines. Cahiers Archéologiques XIX. 1969, 1-27. 